\title{
Effects of agricultural land use on fluvial carbon dioxide, methane and nitrous oxide concentrations in a large European river, the Meuse (Belgium)
}

\author{
A.V. Borges ${ }^{\mathrm{a}, *}$, F. Darchambeau ${ }^{\mathrm{a}, 1}$, T. Lambert $^{\mathrm{a}, 2}$, S. Bouillon $^{\mathrm{b}}$, C. Morana $^{\mathrm{b}}$, S. Brouyère $^{\mathrm{c}}$, V. Hakoun $^{\mathrm{c}, 3}$, \\ A. Jurado ${ }^{c}$, H.-C. Tseng ${ }^{\text {a }}$, J.-P. Descy ${ }^{\text {a }}$, F.A.E. Roland ${ }^{\text {a }}$ \\ a Chemical Oceanography Unit, University of Liège, Liège, Belgium \\ ${ }^{\mathrm{b}}$ Department of Earth and Environmental Sciences, KU Leuven, Leuven, Belgium \\ c Hydrogeology and Environmental Geology, University of Liège, Liège, Belgium
}

\section{H I G H L I G H T S}

- Large data-set of $\mathrm{CO}_{2}, \mathrm{CH}_{4}$, and $\mathrm{N}_{2} \mathrm{O}$ in the surface waters of the Meuse River

- Highest fluvial $\mathrm{CO}_{2}, \mathrm{CH}_{4}$, and $\mathrm{N}_{2} \mathrm{O}$ concentrations during low water

- Highest fluvial $\mathrm{CO}_{2}, \mathrm{CH}_{4}$ and $\mathrm{N}_{2} \mathrm{O}$ concentrations in agriculture dominated catchments
G R A P H I C A L A B S T RACT

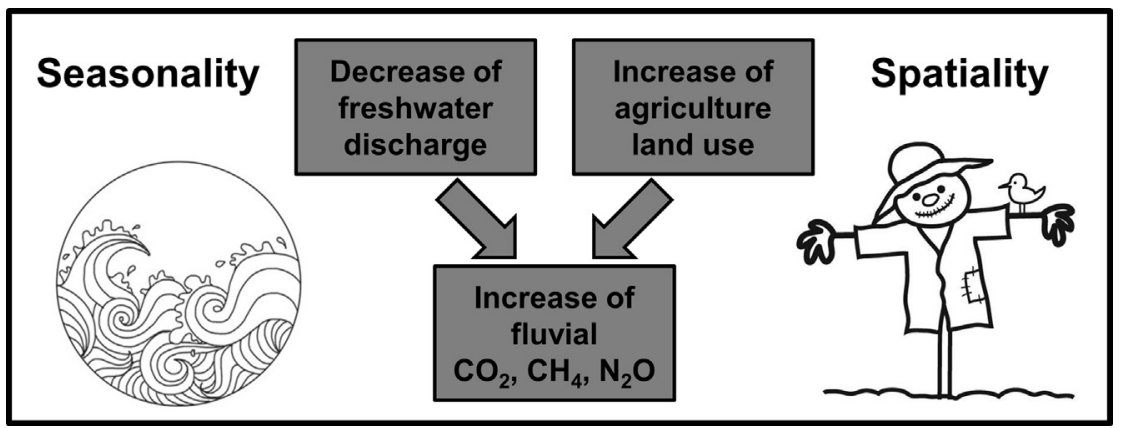

\section{A R T I C L E I N F O}

\section{Article history:}

Received 3 July 2017

Received in revised form 4 August 2017

Accepted 5 August 2017

Available online $\mathrm{xxxx}$

Editor: D. Barcelo

\section{Keywords:}

Meuse river

Carbon dioxide

Methane

Nitrous oxide

Land use

Agriculture

\begin{abstract}
A B S T R A C T
We report a data-set of $\mathrm{CO}_{2}, \mathrm{CH}_{4}$, and $\mathrm{N}_{2} \mathrm{O}$ concentrations in the surface waters of the Meuse river network in Belgium, obtained during four surveys covering 50 stations (summer 2013 and late winter 2013, 2014 and 2015), from yearly cycles in four rivers of variable size and catchment land cover, and from 111 groundwater samples. Surface waters of the Meuse river network were over-saturated in $\mathrm{CO}_{2}, \mathrm{CH}_{4}, \mathrm{~N}_{2} \mathrm{O}$ with respect to atmospheric equilibrium, acting as sources of these greenhouse gases to the atmosphere, although the dissolved gases also showed marked seasonal and spatial variations. Seasonal variations were related to changes in freshwater discharge following the hydrological cycle, with highest concentrations of $\mathrm{CO}_{2}, \mathrm{CH}_{4}, \mathrm{~N}_{2} \mathrm{O}$ during low water owing to a longer water residence time and lower currents (i.e. lower gas transfer velocities), both contributing to the accumulation of gases in the water column, combined with higher temperatures favourable to microbial processes. Inter-annual differences of discharge also led to differences in $\mathrm{CH}_{4}$ and $\mathrm{N}_{2} \mathrm{O}$ that were higher in years with prolonged low water periods. Spatial variations were mostly due to differences in land cover over the catchments, with systems dominated by agriculture (croplands and pastures) having higher $\mathrm{CO}_{2}, \mathrm{CH}_{4}, \mathrm{~N}_{2} \mathrm{O}$ levels than forested systems. This seemed to be related to higher levels of dissolved and particulate organic matter, as well as dissolved inorganic nitrogen in agriculture dominated systems compared to forested ones. Groundwater had very low $\mathrm{CH}_{4}$ concentrations in the shallow and unconfined aquifers (mostly fractured limestones) of the
\end{abstract}

\footnotetext{
* Corresponding author.

E-mail address: alberto.borges@ulg.ac.be (A.V. Borges).

1 Present address: Direction générale opérationnelle Agriculture, Ressources naturelles et Environnement, Service Publique de Wallonie, Belgium.

2 Present address: University of Lausanne, Institute of Earth Surface Dynamics, Lausanne, Switzerland.

3 Present address: Spanish National Research Council, Madrid, Spain.
} 
Meuse basin, hence, should not contribute significantly to the high $\mathrm{CH}_{4}$ levels in surface riverine waters. Owing to high dissolved concentrations, groundwater could potentially transfer important quantities of $\mathrm{CO}_{2}$ and $\mathrm{N}_{2} \mathrm{O}$ to surface waters of the Meuse basin, although this hypothesis remains to be tested.

(C) 2017 Elsevier B.V. All rights reserved.

\section{Introduction}

Inland waters are important players in the global budgets of longlived green-house gases (GHGs), acting as vigorous sources to the atmosphere of carbon dioxide $\left(\mathrm{CO}_{2}\right)$ (Raymond et al., 2013; Lauerwald et al., 2015; Borges et al., 2015a), methane $\left(\mathrm{CH}_{4}\right)$ (Bastviken et al., 2011; Borges et al., 2015a; Stanley et al., 2016), and nitrous oxide $\left(\mathrm{N}_{2} \mathrm{O}\right)$ (Seitzinger and Kroeze, 1998; Hu et al., 2016). The largest fraction of global $\mathrm{CO}_{2}$ and $\mathrm{CH}_{4}$ emissions from riverine networks occurs at tropical and sub-tropical latitudes (Bloom et al., 2010; Raymond et al., 2013; Lauerwald et al., 2015; Borges et al., 2015b) that are in general more pristine than their temperate counter-parts. Conversely, the largest fraction of global $\mathrm{N}_{2} \mathrm{O}$ emissions from riverine networks is assumed to occur in human impacted temperate rivers (Seitzinger and Kroeze, 1998; Hu et al., 2016).

In pristine river networks, $\mathrm{CO}_{2}$ and $\mathrm{CH}_{4}$ emissions are driven by instream production related to the degradation of terrestrial organic matter (Cole and Caraco, 2001; Richey et al., 2002), as well as lateral inputs from groundwater and/or wetlands (Abril et al., 2014; Borges et al., 2015a, 2015b). Pristine rivers are usually nitrogen poor and seem to be low sources or even sinks of $\mathrm{N}_{2} \mathrm{O}$, related to sediment denitrification that removes $\mathrm{N}_{2} \mathrm{O}$ from the water column (Richey et al., 1988; Baulch et al., 2011; Borges et al., 2015a).

In strongly human influenced rivers typically located in Europe, North America, Asia and Australia, the $\mathrm{CO}_{2}, \mathrm{CH}_{4}$ and $\mathrm{N}_{2} \mathrm{O}$ dynamics are modified in several ways. Organic matter inputs from wastewater enhance organic matter degradation and the production of $\mathrm{CO}_{2}$ and $\mathrm{CH}_{4}$ (Abril et al., 2000; Garnier et al., 2013; Marwick et al., 2014); effluents from wastewater treatment plants are enriched in $\mathrm{CO}_{2}$ and $\mathrm{CH}_{4}$ that are degassed within the river network (Alshboul et al., 2016). In extreme cases of wastewater pollution, anoxic conditions will lead to low $\mathrm{N}_{2} \mathrm{O}$ levels due to denitrification (Rajkumar et al., 2008), but in oxic conditions nitrification fuelled by $\mathrm{NH}_{4}^{+}$inputs from wastewater leads to $\mathrm{N}_{2} \mathrm{O}$ production (Garnier et al., 2009; Yu et al., 2013; Marwick et al., 2014). Impoundments increase water residence time that favour organic matter sedimentation and $\mathrm{CH}_{4}$ production (Maeck et al., 2013; Crawford et al., 2016). Increased water residence time and water transparency due to impoundments can lead to low $\mathrm{CO}_{2}$ levels related to enhanced primary production (Crawford et al., 2016). Agriculture can enhance mobilisation of labile soil organic matter (Wilson and Xenopoulos, 2009; Graeber et al., 2012, 2015; Lambert et al., 2017) and potentially enhance organic matter degradation and the production of $\mathrm{CO}_{2}$ and $\mathrm{CH}_{4}$ in rivers, although this has been seldom investigated (Bodmer et al., 2016). Leaching of nitrogen from artificial fertilizers from agricultural soils leads to enhanced in-stream $\mathrm{N}_{2} \mathrm{O}$ production, presumably related to enhanced denitrification (Beaulieu et al., 2011). Enhanced nutrient inputs will fuel primary production leading to low $\mathrm{CO}_{2}$ and high $\mathrm{CH}_{4}$ concentrations, the latter related to enhanced organic matter delivery to sediments (Crawford et al., 2016). Other human impacts that affect carbon and nitrogen cycling in river networks that can potentially influence cycling of GHGs are river bank stabilization and floodplain drainage that disrupt the river-wetland connectivity that is important for $\mathrm{CO}_{2}$ and $\mathrm{CH}_{4}$ dynamics in rivers (Abril et al., 2014; Teodoru et al., 2015; Borges et al., 2015a, 2015b; Sieczko et al., 2016).

The introduction of invasive animal species such as the zebra mussel (Dreissena polymorpha) in US rivers and lakes (Caraco et al., 1997; Evans et al., 2011) and the Asian clam (Corbicula spp.) in European rivers, including the Meuse (Descy et al., 2003; Pigneur et al., 2014) led to major changes in phytoplankton dynamics, with potential but undocumented effects on GHGs fluxes. Several alien aquatic plants have been reported in European inland waters (Hussner, 2012), some with high production and biomass (Hussner, 2009); invasive floating macrophytes such as the water hyacinth (Eichhornia crassipes) have been documented to increase $\mathrm{CO}_{2}$ and $\mathrm{CH}_{4}$ levels in tropical rivers (Koné et al., $2009,2010)$, but this remains undocumented in temperate rivers.

We report a dataset of $\mathrm{CO}_{2}, \mathrm{CH}_{4}$, and $\mathrm{N}_{2} \mathrm{O}$ concentrations in the surface waters of the Meuse river network in Belgium, obtained during four surveys of 50 stations (summer 2013 and late winter 2013, 2014 and 2015), and from yearly monitoring at four rivers of variable catchment size and land cover (Table 1). The aim of this study is to describe the temporal and spatial variability of $\mathrm{CO}_{2}, \mathrm{CH}_{4}$, and $\mathrm{N}_{2} \mathrm{O}$ concentrations and to check if the spatial variability can be related to catchment land use. The Meuse is a large European river (total length $885 \mathrm{~km}$, catchment of $\sim 34,550 \mathrm{~km}^{2}$, average annual discharge of $10 \mathrm{~km}^{3} \mathrm{yr}^{-1}$ ) that rises in eastern France and flows through Belgium and The Netherlands before discharging into the North Sea in conjunction with the Rhine. It is densely populated $\left(\sim 710^{6}\right.$ inhabitants, $\sim 200$ inhabitants $\left.\mathrm{km}^{-2}\right)$ and has experienced numerous impacts from human activities since the 19th century such as river bank stabilization, and eutrophication related to nutrient leaching from croplands and waste water from cities (Descy et al., 2009). Throughout the catchment, there has been a large conversion of forests to agriculture and pastures, as well as urbanization. In the Meuse basin situated in Belgium (Wallonia) about 34\% of the catchment is covered on average by croplands, $15 \%$ by pastures, $37 \%$ by forests, and $13 \%$ by urban areas; major cities along water courses are Charleroi (205,000 inhabitants), Liège (196,000 inhabitants), Namur (110,000 inhabitants), and Verviers (57,000 inhabitants). Nowadays, about $96 \%$ of the wastewater from urban agglomerations in Wallonia is collected, while $84 \%$ is effectively treated in wastewater treatment plants, meaning that only $20 \%$ of domestic wastewater is delivered untreated directly into streams and rivers.

\section{Material and methods}

Four surveys of 50 stations (Fig. 1 ) were carried out (08-01-13 to 1504-13; $12-07-13$ to $31-07-13 ; 18-02-14$ to $27-03-14$; 03-02-15 to $12-$ 03-15) covering 35 sub-basins. The duration of each survey was different because sampling on some occasions was not possible mainly due to bad weather conditions (snow or heavy rains), in particular during

\section{Table 1}

Characteristics of four rivers in the Meuse basin that were monitored from February 2011 to February 2013 (July 2014 for the Meuse station). Catchment surface and fresh-water discharge correspond to values upstream of sampling point (Fig. 1) and not the values of the whole river basin.

\begin{tabular}{lllll}
\hline & Meuse & Ourthe & Geer & Colonster \\
\hline Catchment $\left(\mathrm{km}^{2}\right)$ & 16,672 & 1837 & 115 & 19 \\
Fresh-water discharge ${ }^{\mathrm{a}}\left(\mathrm{m}^{3} \mathrm{~s}^{-1}\right)$ & 207 & 41 & 0.5 & n.d. \\
Channel width (m) & 110 & 50 & 8 & 1 \\
Land cover & & & & \\
$\quad$ Urban (\%) & 8.5 & 6.3 & 25.8 & 28.0 \\
Croplands (\%) & 32.5 & 28.2 & 74.2 & 0.0 \\
Pasture (\%) & 21.8 & 20.7 & 0.0 & 6.4 \\
Forest (\%) & 34.9 & 43.3 & 0.0 & 65.6 \\
Grassland (\%) & 2.0 & 1.3 & 0.0 & 0.0 \\
Wetlands (\%) & 0.0 & 0.2 & 0.0 & 0.0 \\
\hline
\end{tabular}

\footnotetext{
a Average 2011-2014.
} 


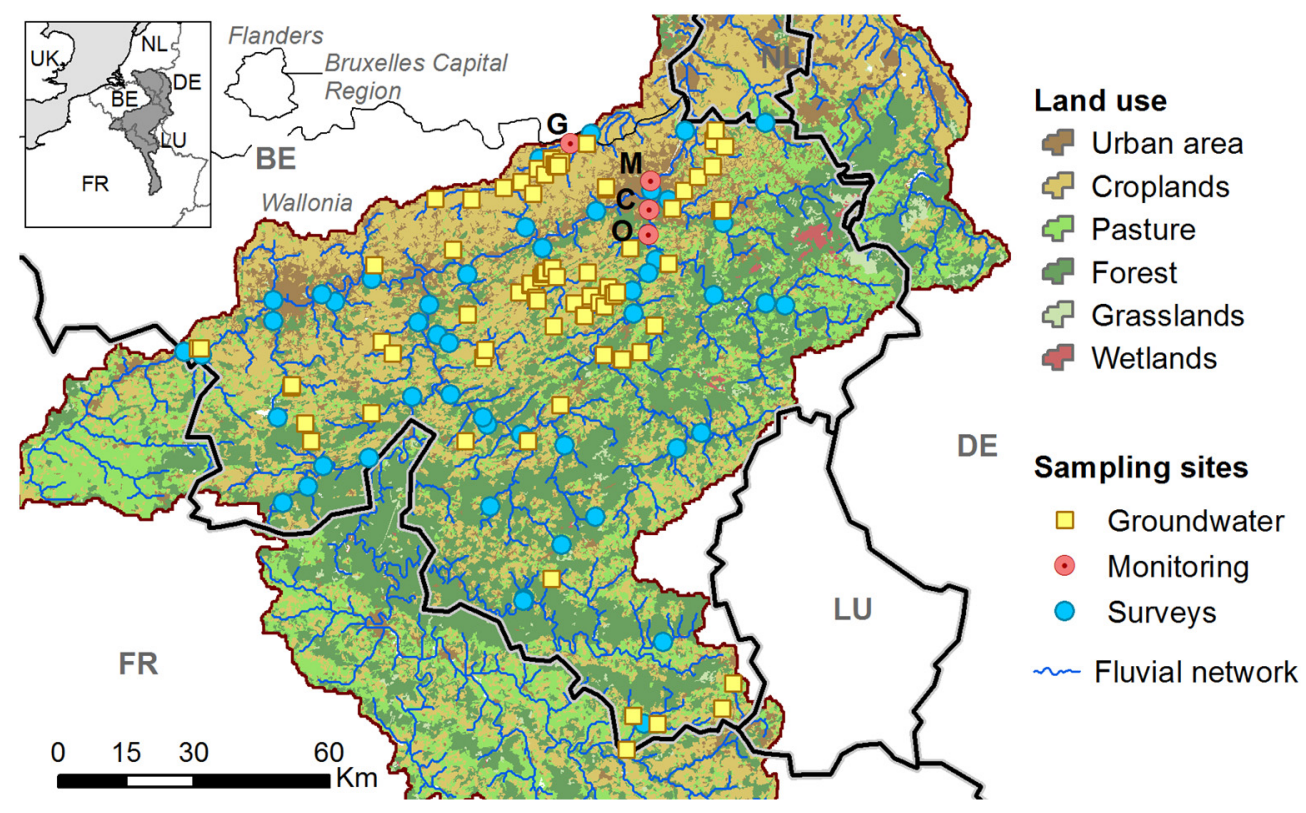

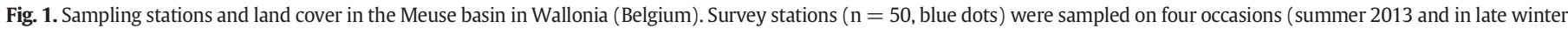

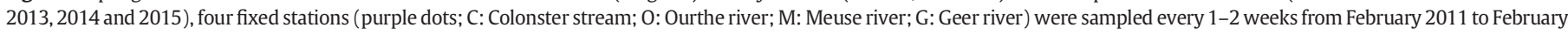

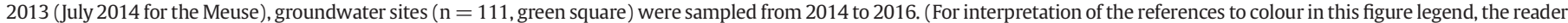
is referred to the web version of this article.)

late winter 2013. Four fixed stations were monitored at weekly intervals during rising-high-declining water period and every two weeks during low water at four rivers (Table 1 ), from $07-02-11$ to $28-02-13$ for the Ourthe, Geer and Colonster rivers, and from 07-02-11 to 03-07-14 for the Meuse river. Groundwater was sampled at 111 stations from 15-09-14 to 26-10-16.

$\mathrm{CH}_{4}$ and $\mathrm{N}_{2} \mathrm{O}$ were sampled at all stations, and the partial pressure of $\mathrm{CO}_{2}\left(\mathrm{pCO}_{2}\right)$ was measured during the last three spatial surveys, and during the last year of monitoring of the Meuse river. Sampling was carried out in surface waters from the shore or from bridges using a 1.7 L Niskin bottle (General Oceanics) for dissolved gases, and a polyethylene bucket $\left(5 \mathrm{~L}\right.$ ) for other variables. Samples for $\mathrm{CH}_{4}$ and $\mathrm{N}_{2} \mathrm{O}$ were transferred with tubing from the Niskin bottle to $50 \mathrm{ml}$ borosilicate serum bottles that were poisoned with a saturated solution of $\mathrm{HgCl}_{2}(100 \mu \mathrm{l})$, sealed with a butyl stopper and crimped with an aluminum cap. Four polypropylene syringes of $60 \mathrm{ml}$ for measurements of $\mathrm{pCO}_{2}$ were also filled from the Niskin bottle. River water was stored in a polyethylene $2 \mathrm{~L}$ bottle for further processing in the laboratory. Water temperature, specific conductivity, $\mathrm{pH}$ and dissolved oxygen were measured with a multiprobe (YSI ProPlus). Groundwater samples were collected in a similar fashion, with pumps from piezometers, after stabilization of the water temperature and electrical conductivity monitored with a portable probe.

The concentrations of dissolved $\mathrm{CH}_{4}$ and $\mathrm{N}_{2} \mathrm{O}$ were measured with the head-space equilibration technique (Weiss, 1981) and a gas chromatograph fitted with a flame ionisation detector and an electron capture detector (SRI 8610C) calibrated with $\mathrm{CH}_{4}: \mathrm{CO}_{2}: \mathrm{N}_{2} \mathrm{O}: \mathrm{N}_{2}$ mixtures (Air Liquide Belgium) of 1,10 and $30 \mathrm{ppm} \mathrm{CH}_{4}$ and of $0.2,2.0$ and $6.0 \mathrm{ppm} \mathrm{N}_{2} \mathrm{O}$. The $\mathrm{pCO}_{2}$ was measured with an infra-red gas analyser (Li-Cor Li-840) within minutes after sampling, with head-space equilibration technique (Abril et al., 2015) by creating a headspace with ambient air in the polypropylene syringes (1:1 ratio of air and water). The Li-840 was calibrated with a suite of $\mathrm{CO}_{2}: \mathrm{N}_{2}$ mixtures (Air Liquide Belgium) with mixing ratios of $388,813,3788$ and $8300 \mathrm{ppm} \mathrm{CO}_{2}$. The reproducibility of measurements was $\pm 2.0, \pm 3.9$, and $\pm 3.2 \%$ for $\mathrm{pCO}_{2}$, $\mathrm{CH}_{4}$, and $\mathrm{N}_{2} \mathrm{O}$, respectively.

Water was filtered on Macherey-Nagel $47 \mathrm{~mm}$ diameter GF-5 filters for the determination of chlorophyll-a (Chl-a) concentration that were stored frozen $\left(-20^{\circ} \mathrm{C}\right)$. Total suspended matter (TSM) was determined after filtration of water on pre-weighted and pre-combusted ( $4 \mathrm{~h}$ at 500
${ }^{\circ} \mathrm{C}$ ) Whatman GF/F $47 \mathrm{~mm}$ diameter filters. Samples for particulate organic carbon (POC) were filtered on pre-combusted $\left(4 \mathrm{~h}\right.$ at $500{ }^{\circ} \mathrm{C}$ ) Whatman GF/F $25 \mathrm{~mm}$ diameter filters. The filtrate was further filtered on polyethersulfone syringe filters ( $0.2 \mu \mathrm{m}$ porosity) for samples to determine dissolved organic carbon (DOC) that were stored in $40 \mathrm{ml}$ borosilicate vials with polytetrafluoroethylene (PTFE) coated septa and poisoned with $50 \mu \mathrm{L}$ of $\mathrm{H}_{3} \mathrm{PO}_{4}(85 \%)$, and for samples to determine inorganic nutrients $\left(\mathrm{NO}_{3}^{-}, \mathrm{NO}_{2}^{-}\right.$and $\left.\mathrm{NH}_{4}^{+}\right)$that were stored frozen $\left(-20^{\circ} \mathrm{C}\right)$ in $50 \mathrm{ml}$ polypropylene vials.

Chl-a concentration was analysed by high performance liquid chromatography on acetone (90\%) extracts, according to Descy et al. (2005), using a Waters system equipped with a Waters 996 photo-diode array detector. POC concentration was determined with elemental analyser - isotope ratio mass spectrometer (EA-IRMS, ThermoFinnigan Flash HT and Delta V Advantage). DOC concentration was determined with a wet oxidation total organic carbon analyser (IO Analytical Aurora $1030 \mathrm{~W}$ ) coupled with an EA-IRMS (ThermoFinnigan DeltaV Advantage). $\mathrm{NO}_{3}^{-}$and $\mathrm{NO}_{2}^{-}$were determined with the sulfanilamide colorimetric with the vanadium reduction method (APHA, 1998), and $\mathrm{NH}_{4}^{+}$with the dichloroisocyanurate-salicylate-nitroprussiate colorimetric method (SCA, 1981).

Data on land cover were retrieved from the CORINE land cover dataset (EEA, 2014) using the geographic information system software ArcGis ${ }^{\circledR}(10.3 .1)$.

The georeferenced and timestamped data-set is available in a Supplemental File.

\section{Results and discussion}

Minimal temperatures were observed in late winter and maximal values in mid-summer in the Meuse, Ourthe, Geer and Colonster rivers, during the annual monitorings of 2011 and 2012 (Fig. 2, Table 1).

The seasonal amplitude of water temperature was lower in the Colonster stream $\left(\sim 14^{\circ} \mathrm{C}\right)$, a small system under forest canopy than in the large Meuse main-stem $\left(\sim 23^{\circ} \mathrm{C}\right)$. Chl-a concentrations were minimal in the forested Colonster stream; high Chl-a concentrations in the Meuse (up to $80 \mu \mathrm{g} \mathrm{L}^{-1}$ ) were observed during the spring diatom bloom. The average Chl-a in the Meuse from early March to late September was $\sim 20 \mu \mathrm{g} \mathrm{L}^{-1}$ in 2011 , but was $\sim 40 \mu \mathrm{g} \mathrm{L}^{-1}$ for the same period of 

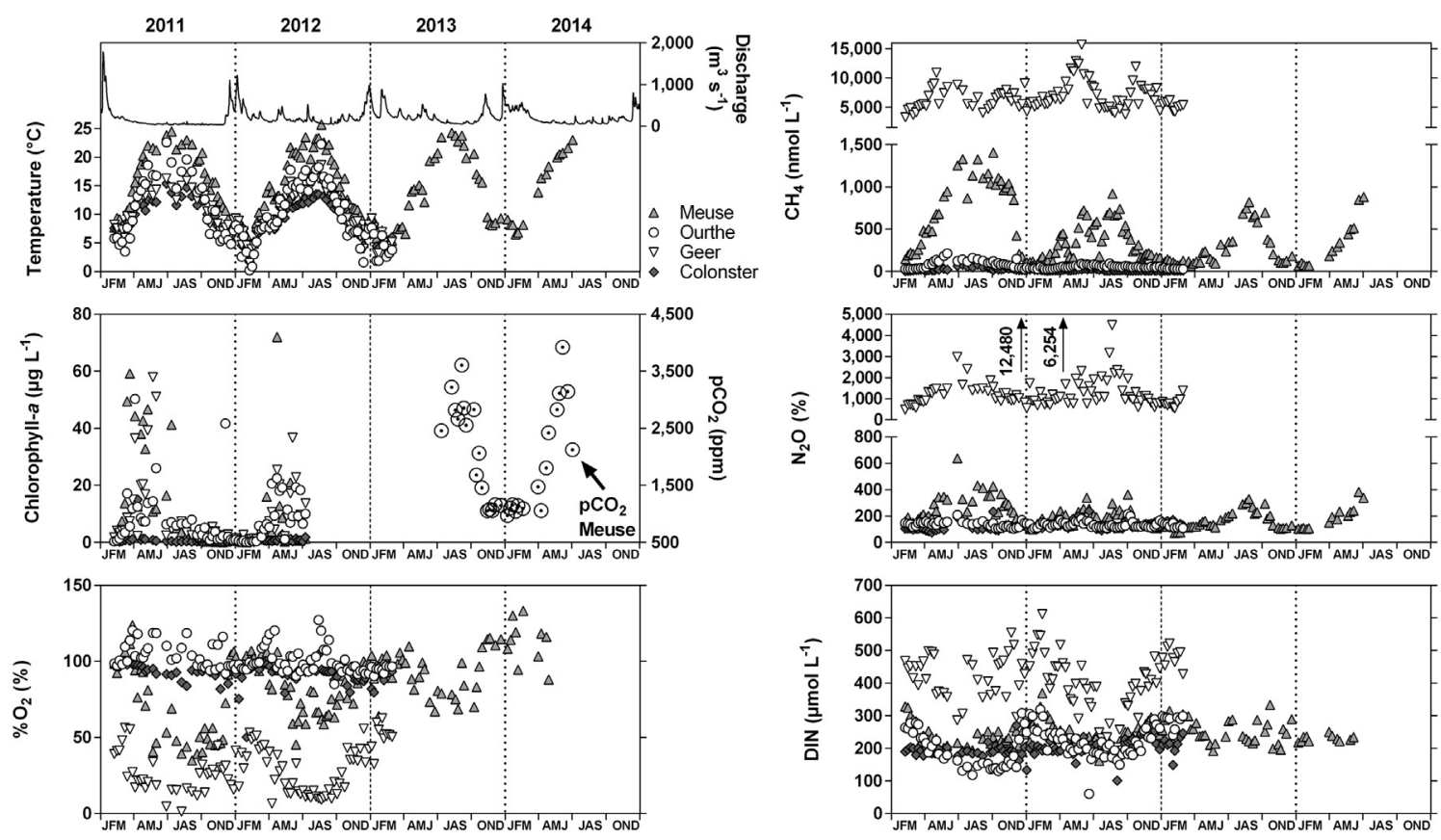

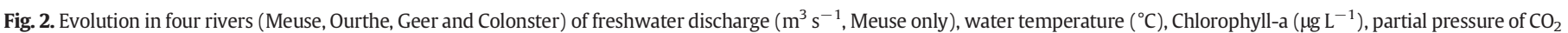
$\left(\mathrm{pCO}_{2}\right.$, ppm, Meuse only), oxygen saturation level $\left(\% \mathrm{O}_{2}, \%\right)$, dissolved $\mathrm{CH}_{4}$ concentration ( $\left.\mathrm{nmol} \mathrm{L}^{-1}\right), \mathrm{N}_{2} \mathrm{O}$ saturation level (\%), and dissolved inorganic nitrogen (DIN, $\mu$ mol $\left.\mathrm{L}^{-1}\right)$.

the year in 2000 (Descy et al., 2002), and $\sim 42 \mu \mathrm{g} \mathrm{L}{ }^{-1}$ in 1984 (Descy et al., 1987). The Chl-a peaked in spring in 2010-2011, and strongly declined in summer, contrary most observations made before the 2000s, when phytoplankton also developed throughout summer and autumn (Everbecq et al., 2001). These changes most probably reflect the effect of population growth of invasive benthic filter-feeders such as the zebra mussel (Dreissena polymorpha), the quagga mussel (Dreissena rostriformis) and the Asian clam (Corbicula spp.) (Descy et al., 2003; Pigneur et al., 2014; Marescaux et al., 2015). Surface waters were close to saturation regarding dissolved oxygen in the forested Colonster stream (average $\% \mathrm{O}_{2}=92 \%$ ) and in the Ourthe (average $\% \mathrm{O}_{2}=$ $101 \%$ ), distinctly under-saturated in the Geer river (average $\% \mathrm{O}_{2}=$
$29 \%$ ) and the Meuse (average $\% \mathrm{O}_{2}=86 \%$ ) (Table 2 ). Minimal $\% \mathrm{O}_{2}$ values were observed in summer in both the Meuse and the Geer rivers, coinciding with maximal values of $\mathrm{pCO}_{2}$ in the Meuse. This is consistent with the summer time maximum of bacterial biomass and production in the Meuse (Servais, 1989). $\mathrm{CH}_{4}$ concentrations were well above the value at equilibrium with the atmosphere $\left(\sim 2 \mathrm{nmol} \mathrm{L}^{-1}\right)$, and were highest in the Geer river (average $6709 \mathrm{nmol} \mathrm{L}^{-1}$ ) followed by the Meuse (average $422 \mathrm{nmol} \mathrm{L}^{-1}$ ) and lowest in the Colonster river (average $20 \mathrm{nmol} \mathrm{L}^{-1}$ ), and the Ourthe (average $66 \mathrm{nmol} \mathrm{L}^{-1}$ ) (Table 2). Similarly, $\mathrm{N}_{2} \mathrm{O}$ saturation levels were well above equilibrium (100\%), and were distinctly higher in the Geer river (average $1406 \%$, i.e. $168 \mathrm{nmol} \mathrm{L}^{-1}$ ) than in the Colonster river (average 127\%, i.e. $16 \mathrm{nmol} \mathrm{L}^{-1}$ ), followed by the

Table 2

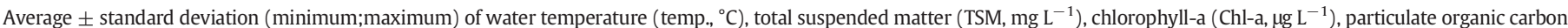

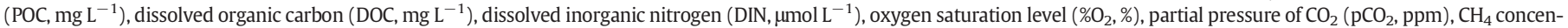

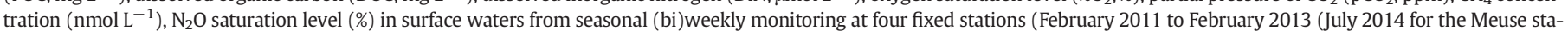
tion)), from four spatial surveys at 50 stations (summer 2013 and late winter 2013, 2014 and 2015) and 111 stations in groundwater of the Meuse basin in Wallonia (Belgium).

\begin{tabular}{|c|c|c|c|c|c|c|c|c|c|c|}
\hline & $\begin{array}{l}\text { Water temp. } \\
\left({ }^{\circ} \mathrm{C}\right)\end{array}$ & $\begin{array}{l}\text { TSM (mg } \\
\left.\mathrm{L}^{-1}\right)\end{array}$ & $\begin{array}{l}\text { Chl-a ( } \mu \mathrm{g} \\
\left.\mathrm{L}^{-1}\right)\end{array}$ & $\begin{array}{l}\text { POC (mg } \\
\left.\mathrm{L}^{-1}\right)\end{array}$ & $\begin{array}{l}\mathrm{DOC}(\mathrm{mg} \\
\left.\mathrm{L}^{-1}\right)\end{array}$ & $\begin{array}{l}\text { DIN }(\mu \mathrm{mol} \\
\left.\mathrm{L}^{-1}\right)\end{array}$ & $\% \mathrm{O}_{2}(\%)$ & $\mathrm{pCO}_{2}(\mathrm{ppm})$ & $\mathrm{CH}_{4}\left(\mathrm{nmol} \mathrm{L}^{-1}\right)$ & $\mathrm{N}_{2} \mathrm{O}(\%)$ \\
\hline \multicolumn{11}{|c|}{ Seasonal monitoring stations (river) } \\
\hline Meuse & $\begin{array}{l}14.4 \pm 6.1 \\
(2.6 ; 25.7)\end{array}$ & $\begin{array}{l}12.7 \pm 17.1 \\
(1.7 ; 130.0)\end{array}$ & $\begin{array}{l}9.6 \pm 15.0 \\
(0.1 ; 59.2)\end{array}$ & $\begin{array}{l}1.4 \pm 0.6 \\
(0.7 ; 3.2)\end{array}$ & $\begin{array}{l}3.2 \pm 0.7 \\
(1.9 ; 4.8)\end{array}$ & $\begin{array}{l}242 \pm 36 \\
(161 ; 369)\end{array}$ & $\begin{array}{l}85.7 \pm 22.8 \\
(34.9 ; 139.0)\end{array}$ & $\begin{array}{l}2004 \pm 912 \\
(971 ; 3921)\end{array}$ & $\begin{array}{l}422 \pm 339 \\
(62 ; 1407)\end{array}$ & $\begin{array}{l}197 \pm 88 \\
(72 ; 637)\end{array}$ \\
\hline Ourthe & $\begin{array}{l}10.2 \pm 5.4 \\
(0.2 ; 22.6)\end{array}$ & $\begin{array}{l}11.0 \pm 16.9 \\
(0.3 ; 139.2)\end{array}$ & $\begin{array}{l}7.8 \pm 9.4 \\
(0.1 ; 50.3)\end{array}$ & & & $\begin{array}{l}214 \pm 54 \\
(61 ; 319)\end{array}$ & $\begin{array}{l}101.1 \pm 8.5 \\
(85.0 ; 127.2)\end{array}$ & & $\begin{array}{l}66 \pm 37 \\
(25 ; 213)\end{array}$ & $\begin{array}{l}136 \pm 22 \\
(100 ; 214)\end{array}$ \\
\hline Geer & $\begin{array}{l}10.2 \pm 3.8 \\
(1.5 ; 18.6)\end{array}$ & $\begin{array}{l}29.6 \pm 28.4 \\
(7.4 ; 187.2)\end{array}$ & $\begin{array}{l}8.8 \pm 12.2 \\
(0.6 ; 58.0)\end{array}$ & & & $\begin{array}{l}404 \pm 90 \\
(172 ; 611)\end{array}$ & $\begin{array}{l}28.9 \pm 15.0 \\
(1.2 ; 62.5)\end{array}$ & & $\begin{array}{l}6709 \pm 2249 \\
(3275 ; 15,709)\end{array}$ & $\begin{array}{l}1406 \pm 1390 \\
(492 ; 12,480)\end{array}$ \\
\hline Colonster & $\begin{array}{l}9.4 \pm 3.0 \\
(1.7 ; 16.1)\end{array}$ & $\begin{array}{l}7.7 \pm 7.4 \\
(1.0 ; 41.2)\end{array}$ & $\begin{array}{l}0.8 \pm 1.9 \\
(0.1 ; 15.0)\end{array}$ & & & $\begin{array}{l}202 \pm 26 \\
(101 ; 270)\end{array}$ & $\begin{array}{l}92.1 \pm 6.5 \\
(50.2 ; 104.6)\end{array}$ & & $20 \pm 15(4 ; 77)$ & $\begin{array}{l}127 \pm 30 \\
(76 ; 238)\end{array}$ \\
\hline \multicolumn{11}{|c|}{ Spatial surveys (river) } \\
\hline $08-01 / 15-04-13$ & $\begin{array}{l}5.7 \pm 2.0 \\
(0.7 ; 10.8)\end{array}$ & $\begin{array}{l}18.6 \pm 24.3 \\
(0.2 ; 147.5)\end{array}$ & & $\begin{array}{l}1.6 \pm 1.4 \\
(0.3 ; 6.8)\end{array}$ & $\begin{array}{l}2.5 \pm 1.3 \\
(0.9 ; 6.6)\end{array}$ & $\begin{array}{l}291 \pm 123 \\
(59 ; 585)\end{array}$ & $\begin{array}{l}102.7 \pm 12.5 \\
(58.4 ; 161.9)\end{array}$ & & $\begin{array}{l}207 \pm 439 \\
(7 ; 2827)\end{array}$ & $\begin{array}{l}170 \pm 139 \\
(78 ; 923)\end{array}$ \\
\hline $12-07 / 31-07-13$ & $\begin{array}{l}18.1 \pm 3.1 \\
(13.3 ; 25.9)\end{array}$ & $\begin{array}{l}6.7 \pm 4.3 \\
(1.7 ; 20.8)\end{array}$ & & $\begin{array}{l}1.0 \pm 0.5 \\
(0.4 ; 2.7)\end{array}$ & $\begin{array}{l}2.7 \pm 0.9 \\
(1.2 ; 4.8)\end{array}$ & $\begin{array}{l}230 \pm 97 \\
(35 ; 555)\end{array}$ & $\begin{array}{l}90.4 \pm 19.6 \\
(39.4 ; 127.8)\end{array}$ & $\begin{array}{l}2292 \pm 2037 \\
(176 ; 10,033)\end{array}$ & $\begin{array}{l}556 \pm 955 \\
(26 ; 4594)\end{array}$ & $\begin{array}{l}370 \pm 457 \\
(91 ; 2757)\end{array}$ \\
\hline $18-02 / 27-03-14$ & $\begin{array}{l}8.0 \pm 1.1 \\
(5.5 ; 9.9)\end{array}$ & $\begin{array}{l}7.6 \pm 11.2 \\
(0.2 ; 64.5)\end{array}$ & & $\begin{array}{l}1.1 \pm 1.0 \\
(0.3 ; 5.2)\end{array}$ & $\begin{array}{l}2.3 \pm 0.9 \\
(1.0 ; 5.4)\end{array}$ & $\begin{array}{l}264 \pm 110 \\
(50 ; 493)\end{array}$ & $\begin{array}{l}111.4 \pm 14.1 \\
(72.7 ; 141.8)\end{array}$ & $\begin{array}{l}1281 \pm 1450 \\
(34 ; 8151)\end{array}$ & $\begin{array}{l}246 \pm 493 \\
(13 ; 2602)\end{array}$ & $\begin{array}{l}179 \pm 152 \\
(77 ; 730)\end{array}$ \\
\hline $03-02 / 12-03-15$ & $\begin{array}{l}5.6 \pm 1.1 \\
(3.2 ; 7.5)\end{array}$ & $\begin{array}{l}20.4 \pm 29.7 \\
(0.2 ; 111.2)\end{array}$ & & $\begin{array}{l}1.9 \pm 1.7 \\
(0.3 ; 6.7)\end{array}$ & $\begin{array}{l}1.7 \pm 1.0 \\
(0.2 ; 4.3)\end{array}$ & $\begin{array}{l}266 \pm 116 \\
(36 ; 580)\end{array}$ & $\begin{array}{l}108.0 \pm 9.8 \\
(74.0 ; 125.0)\end{array}$ & $\begin{array}{l}1281 \pm 1140 \\
(444 ; 6815)\end{array}$ & $\begin{array}{l}267 \pm 604 \\
(15 ; 3533)\end{array}$ & $\begin{array}{l}180 \pm 129 \\
(86 ; 672)\end{array}$ \\
\hline \multicolumn{11}{|l|}{ Groundwater } \\
\hline & $\begin{array}{l}11.6 \pm 1.9 \\
(8.68 ; 23.0)\end{array}$ & & & & & $\begin{array}{l}526 \pm 406 \\
(0 ; 2592)\end{array}$ & $\begin{array}{l}54.7 \pm 23.7 \\
(1.8 ; 97.4)\end{array}$ & $\begin{array}{l}20,297 \pm 13,420 \\
(1769 ; 100,514)\end{array}$ & $\begin{array}{l}44 \pm 166 \\
(0 ; 1064)\end{array}$ & $\begin{array}{l}7027 \pm 10,016 \\
(11 ; 418,920)\end{array}$ \\
\hline
\end{tabular}



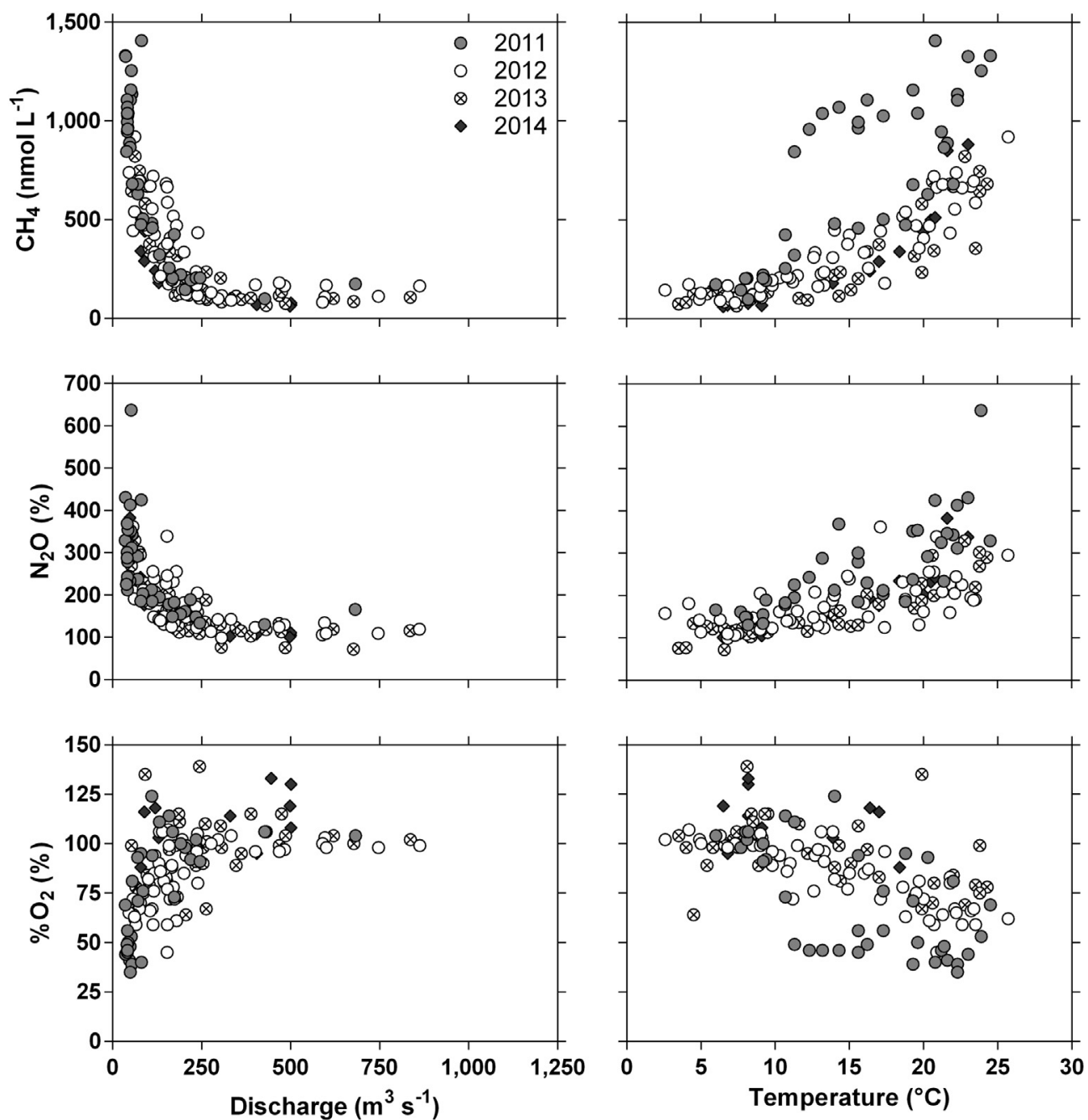

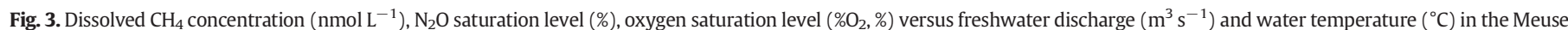
river in 2011, 2012, 2013 and 2014.

Meuse (average 197\%, i.e. $20 \mathrm{nmol} \mathrm{L}^{-1}$ ) and the Ourthe (average $136 \%$, i.e. $17 \mathrm{nmol} \mathrm{L}^{-1}$ ) (Table 2). The $\mathrm{N}_{2} \mathrm{O}$ pattern was consistent with much the higher dissolved inorganic nitrogen (DIN) values in the Geer river (average $404 \mu \mathrm{mol} \mathrm{L}{ }^{-1}$ ) than in the Colonster stream (average 202 $\mu \mathrm{mol} \mathrm{L}{ }^{-1}$ ) (Table 2). The lowest values of $\mathrm{O}_{2}$, and highest values of $\mathrm{CH}_{4}, \mathrm{~N}_{2} \mathrm{O}$ and DIN in the Geer were most probably related to its small size and discharge (leading to high water residence time), as well as the dominance of cropland on its catchment (Table 1 ).

The seasonal cycles of $\mathrm{O}_{2}, \mathrm{CH}_{4}$ and $\mathrm{N}_{2} \mathrm{O}$ were relatively similar in the four rivers (albeit the seasonal amplitudes are very different), with minimal $\% \mathrm{O}_{2}$ and maximal $\mathrm{CH}_{4}$ and $\mathrm{N}_{2} \mathrm{O}$ in summer coinciding with the highest temperatures (Fig. 2). This would suggest an enhancement of microbial activity in summer related to temperature, as suggested by the positive relationship in the Meuse with temperature of $\mathrm{CH}_{4}$ and $\mathrm{N}_{2} \mathrm{O}$, and the negative relationship with temperature of $\% \mathrm{O}_{2}$ (Fig. 3 ).

Similarly, the $\mathrm{pCO}_{2}$ in the Meuse was positively related to temperature and to a specific fraction of the dissolved organic matter (DOM) pool (C6) (Fig. 4) that characterizes in-stream microbially produced compounds (Lambert et al., 2017). Bodmer et al. (2016) showed a similar correlation between $\mathrm{pCO}_{2}$ and DOM composition across a spatial
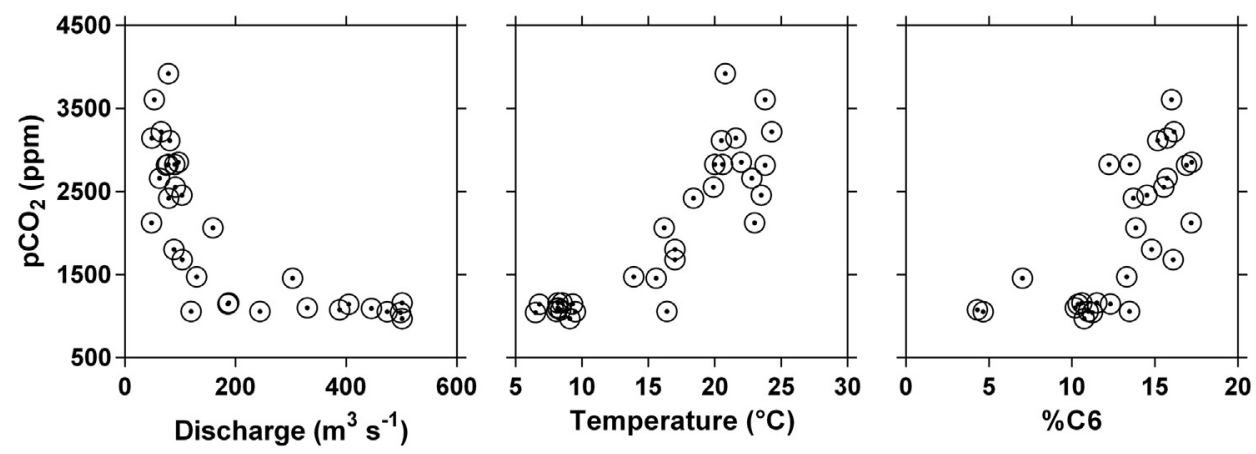

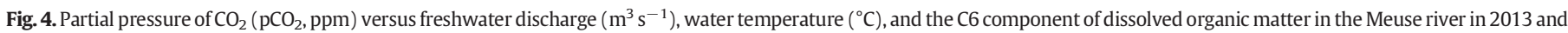
2014. The C6 component is derived from a parallel factor analysis of excitation-emission matrices of dissolved organic matter from a parallel study (Lambert et al., 2017). 

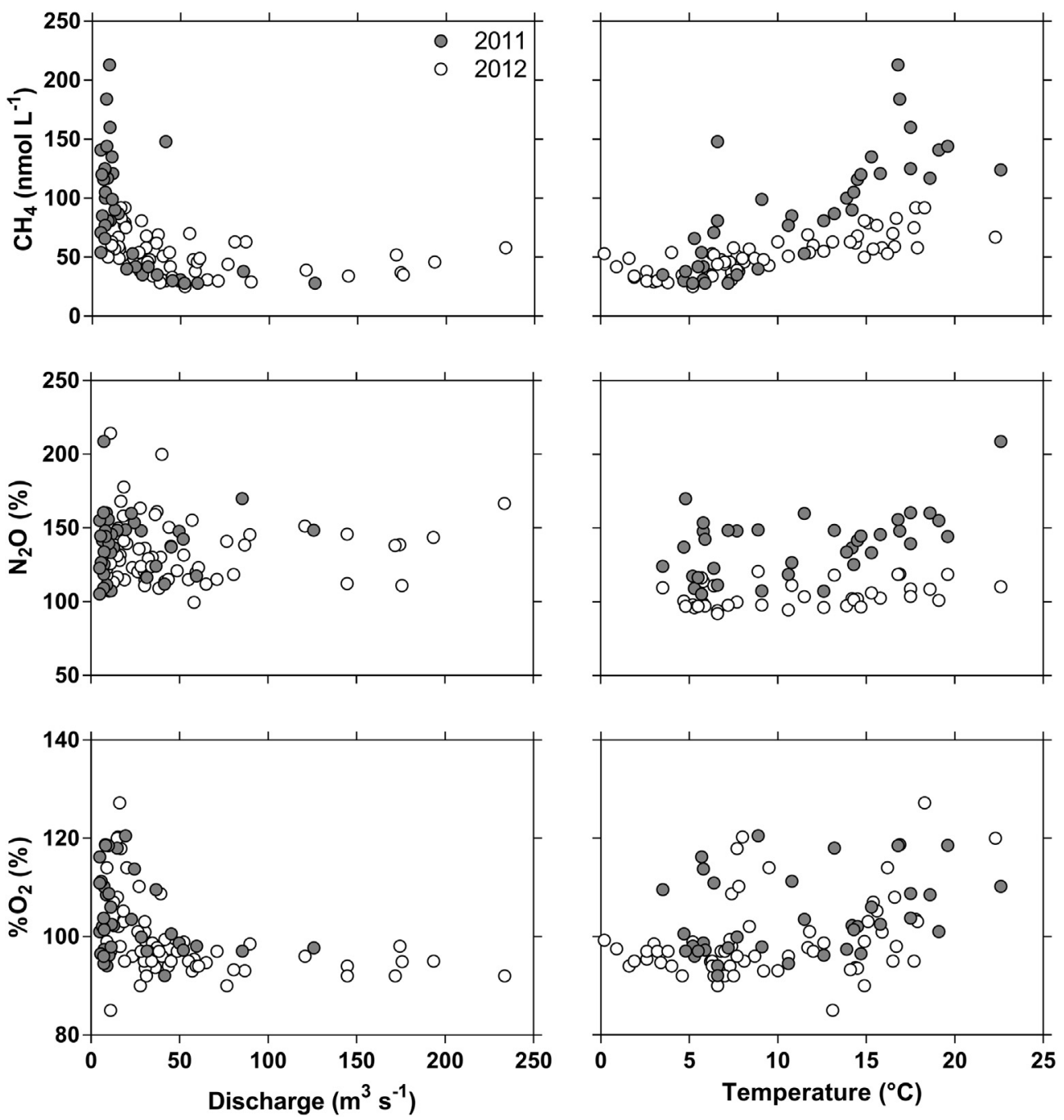

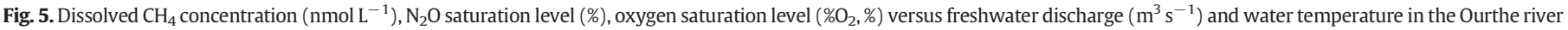
in 2011 and 2012.

gradient of different rivers, while here we show a correlation between those same quantities at a single site but across seasons. The summertime lowering of $\mathrm{O}_{2}$ in the water column should lead to a lower $\mathrm{O}_{2}$ penetration in sediments, enhancing reducing and anoxic conditions in sediments favourable to $\mathrm{CH}_{4}$ and $\mathrm{N}_{2} \mathrm{O}$ production. Finally, the decrease of freshwater discharge in summer leads to an increase of the water residence time, enhancing an accumulation of $\mathrm{CH}_{4}, \mathrm{~N}_{2} \mathrm{O}$ and $\mathrm{CO}_{2}$ in the water, as well as decreasing the loss of these gases to the atmosphere due to the decrease the gas transfer velocity (Raymond et al., 2012). While the increase of $\mathrm{CH}_{4}, \mathrm{~N}_{2} \mathrm{O}$ and $\mathrm{CO}_{2}$ with the lowering of freshwater discharge could also be interpreted as resulting from the increase in groundwater inputs, this would not explain the $\mathrm{CH}_{4}$ distribution, since groundwater in the Meuse basin was characterized by very low $\mathrm{CH}_{4}$ concentrations (see hereafter). A second yearly maximum of $\mathrm{CH}_{4}$ occurs in the Geer basin in late autumn (November) that could be related to agricultural activities such as fertilisation of cropland with manure.

In the Meuse river, the $\mathrm{CH}_{4}$ concentration was distinctly higher in 2011 (yearly maximum of $1407 \mathrm{nmol} \mathrm{L}^{-1}$ ) than the other three following years (yearly maximum ranging between 822 and $920 \mathrm{nmol} \mathrm{L}^{-1}$ ). The low water period was longer and the average discharge was

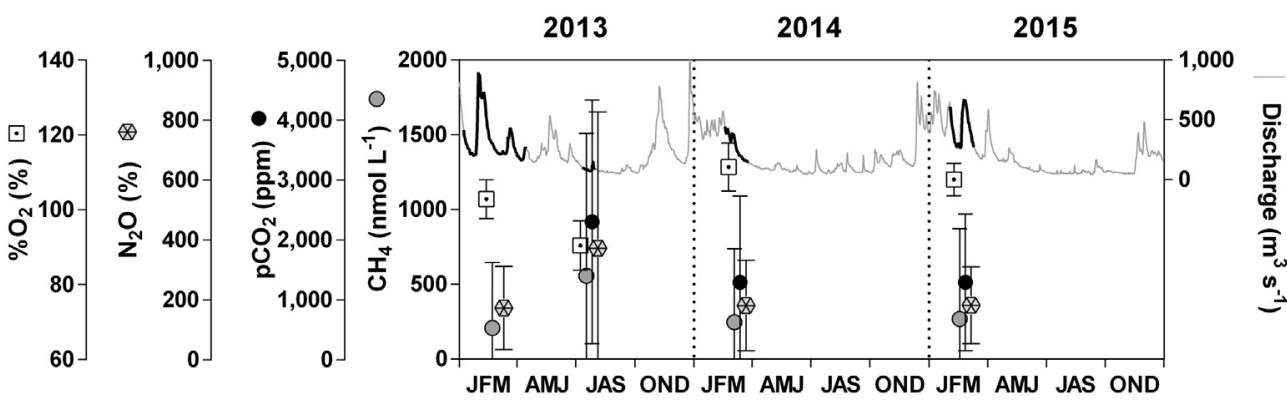

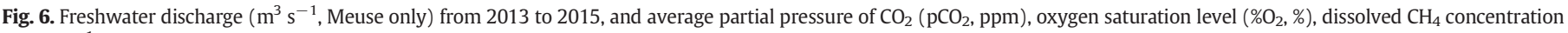

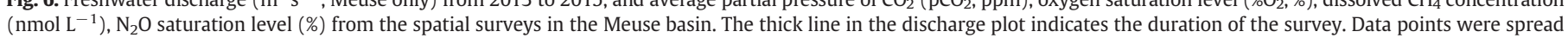
horizontally for clarity, but all variables were sampled simultaneously. 
lower in 2011 compared to the other years, with average discharge from early April to late October of $54 \mathrm{~m}^{3} \mathrm{~s}^{-1}$ in 2011 compared to 148, 156 and $94 \mathrm{~m}^{3} \mathrm{~s}^{-1}$ in 2012, 2013 and 2014, respectively. Also, the minimum daily discharge was lower in $2011\left(31 \mathrm{~m}^{3} \mathrm{~s}^{-1}\right)$ compared to the other years (range $45-51 \mathrm{~m}^{3} \mathrm{~s}^{-1}$ ). The $\mathrm{CH}_{4}$ concentrations in the Meuse were negatively correlated to discharge (Fig. 3), with the highest $\mathrm{CH}_{4}$ values in 2011 associated to the lowest discharge values. We hypothesize that the lower discharge and longer residence time likely promoted $\mathrm{CH}_{4}$ accumulation in the water leading to higher $\mathrm{CH}_{4}$ in the $2011 \mathrm{com}-$ pared to the other years at similar temperatures for values between 10 and $25{ }^{\circ} \mathrm{C}$ (Fig. 3). $\mathrm{N}_{2} \mathrm{O}$ and $\% \mathrm{O}_{2}$ in the Meuse river showed consistent patterns with the one of $\mathrm{CH}_{4}$ (Fig. 3) with higher $\mathrm{N}_{2} \mathrm{O}$ and lower $\% \mathrm{O}_{2}$ in 2011 in particular at low discharge values, and deviations at similar temperatures compared to the other years. Although data are only available in 2011 and 2012, $\mathrm{CH}_{4}$ shows similar patterns in the Ourthe river (Fig. 5), although less obvious for $\mathrm{N}_{2} \mathrm{O}$. However, the $\% \mathrm{O}_{2}$ patterns in the Ourthe were different from the Meuse river, with values well above saturation in summer, in particular at low discharge values. This most probably reflects the effect of primary production from aquatic plants (mostly Ranunculus fluitans) and filamentous green algae such as Cladophora glomerata that reach maximum development in summer, combined to lower water levels and lower water residence time due to lower discharge, both promoting the accumulation of $\mathrm{O}_{2}$ in the water column.

The basin-wide average of $\mathrm{O}_{2}$ and GHGs obtained during the four basin surveys showed similar seasonal variations as those described above for the four "monitoring" sites ( Fig. 2), with highest $\mathrm{pCO}_{2}$, $\mathrm{CH}_{4}$ and $\mathrm{N}_{2} \mathrm{O}$ values in summer and lowest in winter mirrored by the $\% \mathrm{O}_{2}$ variations (Fig. 6 , Table 2 ). Despite the different duration of each of the four sampling surveys, mainly due to bad weather conditions that slowed down sampling on some occasions, the average values of $\mathrm{pCO}_{2}, \mathrm{CH}_{4}$ and $\mathrm{N}_{2} \mathrm{O}$ from the three late winter surveys were very similar (Fig. 6, Table 2). The analysis of the whole dataset ("monitoring" and "survey" merged) suggests a control of both spatial and seasonal variations of $\mathrm{CO}_{2}, \mathrm{CH}_{4}$ and $\mathrm{N}_{2} \mathrm{O}$ by microbial processing, as indicated by the negative relationships between GHGs and $\mathrm{O}_{2}$ (Fig. 7), with the most extreme values observed in the Geer river.

$\mathrm{CH}_{4}$ and $\mathrm{N}_{2} \mathrm{O}$ were not significantly correlated to $\mathrm{NO}_{3}^{-}$and to DOC (not shown), so that the dynamics of these two gases in the Meuse river network did not fit the conceptual model of Schade et al. (2016) developed from data in New Hampshire streams, whereby the $\mathrm{CH}_{4}$ and $\mathrm{N}_{2} \mathrm{O}$ were both positively correlated to DOC, while negatively and positively related to $\mathrm{NO}_{3}^{-}$, respectively. In the global meta-analysis of riverine $\mathrm{CH}_{4}$ by Stanley et al. (2016) there were also no significant correlations between $\mathrm{CH}_{4}$ and DOC or $\mathrm{NO}_{3}^{-}$. However, in the Meuse river network, $\mathrm{CH}_{4}$ was positively linearly correlated to $\mathrm{NH}_{4}^{+}$(not shown, $\mathrm{r}^{2}$ $=0.81, \mathrm{p}<0.0001, \mathrm{n}=648$ ), and $\mathrm{N}_{2} \mathrm{O}$ was positively linearly correlated to $\mathrm{NO}_{2}^{-}$(not shown, $\mathrm{r}^{2}=0.72, \mathrm{p}<0.0001, \mathrm{n}=647$ ) and $\mathrm{NH}_{4}^{+}$(not shown, $\mathrm{r}^{2}=0.62, \mathrm{p}<0.0001, \mathrm{n}=646$ ) (excluding the two highest $\mathrm{N}_{2} \mathrm{O}$ values). A correlation between $\mathrm{N}_{2} \mathrm{O}$ and $\mathrm{NO}_{2}^{-}$has also been shown in English and Welsh rivers by Dong et al. (2005), while a correlation of $\mathrm{N}_{2} \mathrm{O}$ and $\mathrm{NH}_{4}^{+}$has also been shown in the Shanghai river network (Yu et al., 2013). It is unclear if such correlations imply a direct causality or if they are spurious resulting indirectly from a common driver such as $\mathrm{O}_{2}$ variability, as $\mathrm{NO}_{2}^{-}\left(\mathrm{r}^{2}=0.60, \mathrm{p}<0.0001, \mathrm{n}=648\right)$ and $\mathrm{NH}_{4}^{+}\left(\mathrm{r}^{2}=0.63, \mathrm{p}<0.0001, \mathrm{n}=647\right)$ were also correlated to $\% \mathrm{O}_{2}$ (not shown), as $\mathrm{N}_{2} \mathrm{O}$ and $\mathrm{CH}_{4}$ (Fig. 6).

Groundwater can be a source of GHGs to riverine systems in particular in lower order streams and headwaters (Johnson et al., 2008; Hotchkiss et al., 2015). The comparison of $\mathrm{CO}_{2}$ and $\mathrm{CH}_{4}$ in groundwater and riverine waters of the Meuse basin (Fig. 8) shows that part of the $\mathrm{CO}_{2}$ in riverine waters could come from groundwater where the average $\mathrm{pCO}_{2}$ value $(20,297 \mathrm{ppm}$, Table 2$)$ was distinctly higher than in river waters (1684 ppm), and in both cases above atmospheric equilibrium ( 400 ppm).
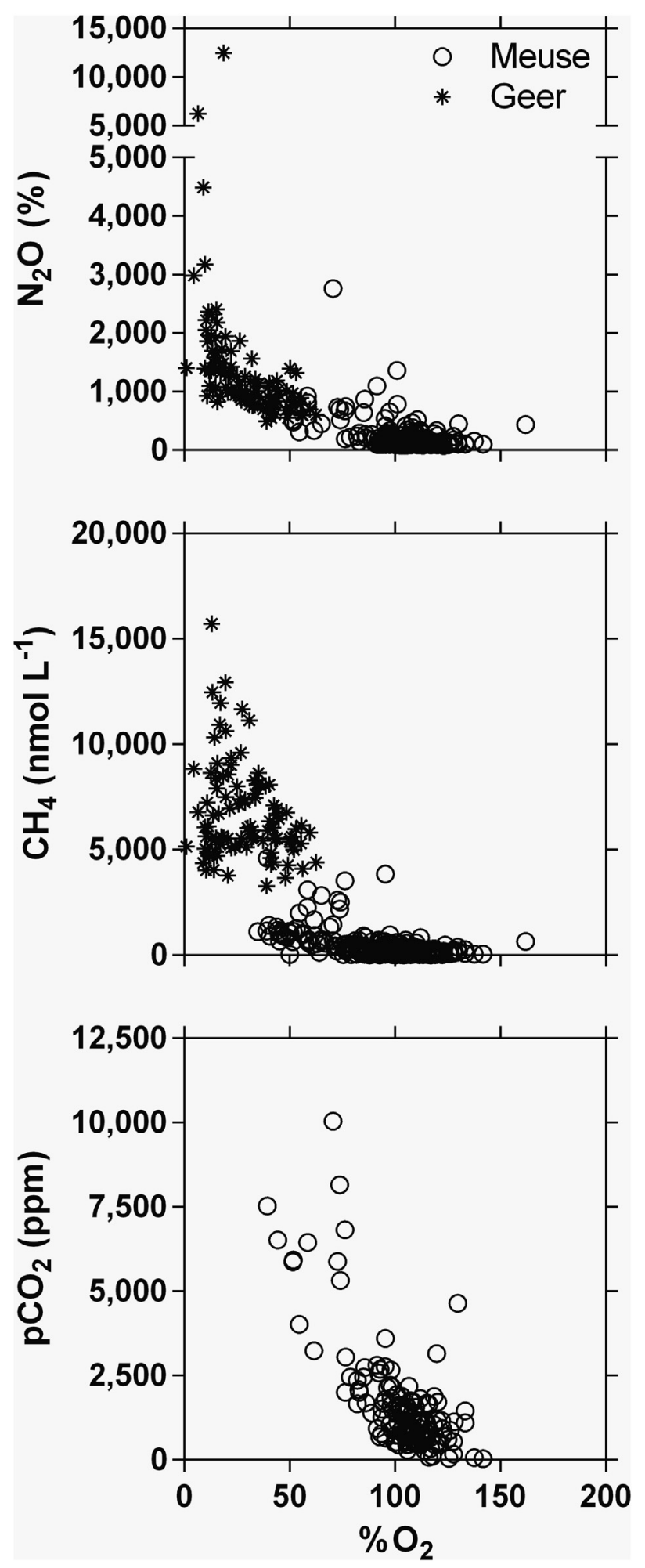

Fig. 7. $\mathrm{N}_{2} \mathrm{O}$ saturation level (\%), dissolved $\mathrm{CH}_{4}$ concentration ( $\mathrm{nmol} \mathrm{L} \mathrm{L}^{-1}$ ), and partial pressure of $\mathrm{CO}_{2}\left(\mathrm{pCO}_{2}\right.$, ppm) versus oxygen saturation level $\left(\% \mathrm{O}_{2}, \%\right)$ for all of the data gathered from fixed station monitoring and spatial surveys in the Meuse basin from 2011 to 2015. Data from the Geer (star) are separated from the other rivers for the basin referred to as "Meuse" (circles).

The opposite was observed for $\mathrm{CH}_{4}$ with a lower average value in groundwater (44 $\mathrm{nmol} \mathrm{\textrm {L } ^ { - 1 }}$, Table 2) than in surface waters ( $360 \mathrm{nmol} \mathrm{L}^{-1}$ ). This would then suggest that the $\mathrm{CH}_{4}$ in river waters in the Meuse basin were produced in-stream or in riparian areas but not discharged through groundwater. Since $\mathrm{pCO}_{2}$ and $\mathrm{CH}_{4}$ in riverine 

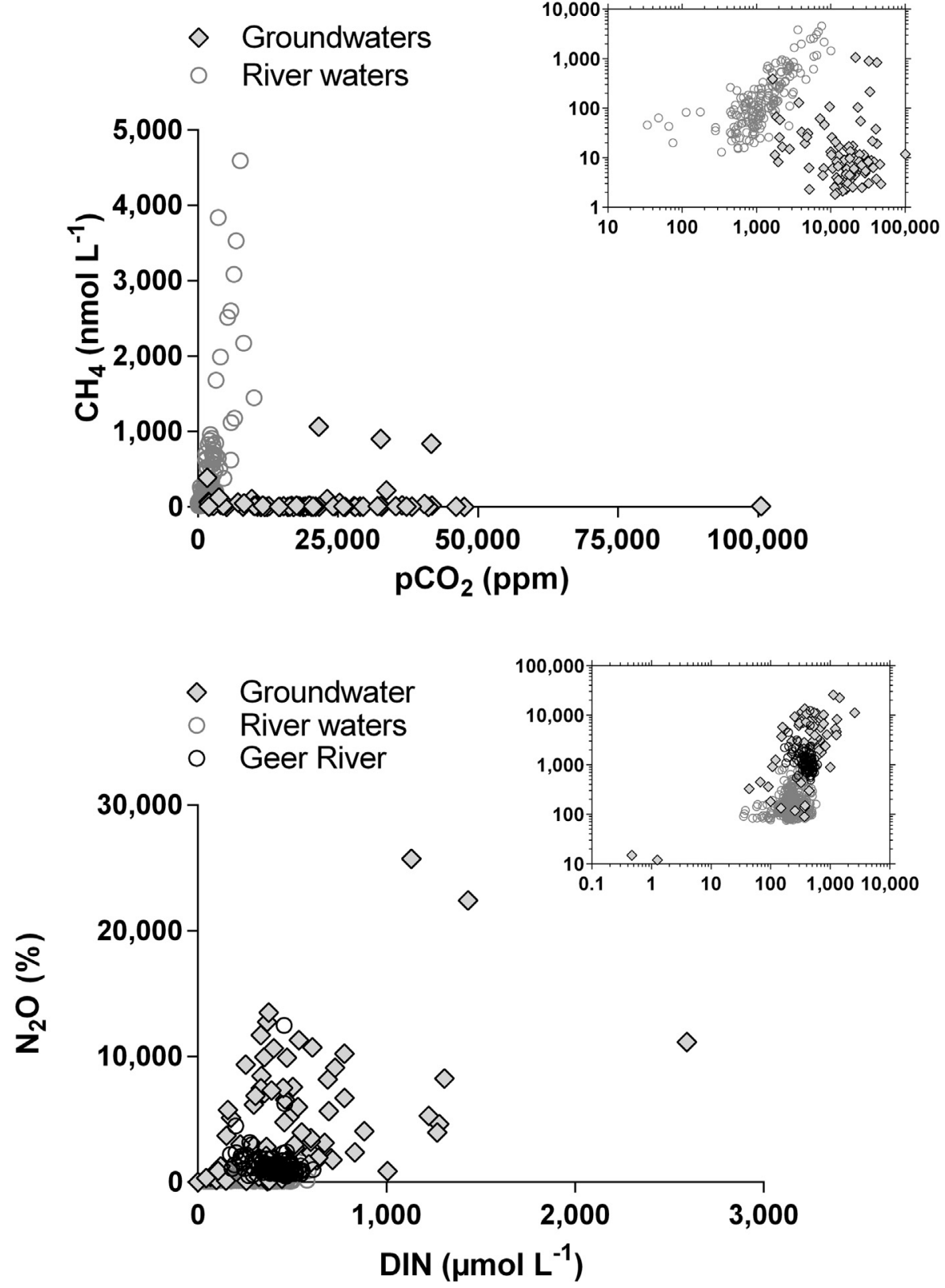

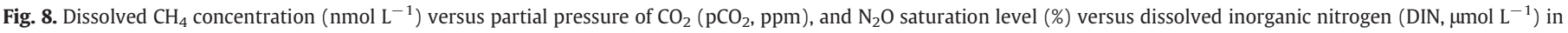

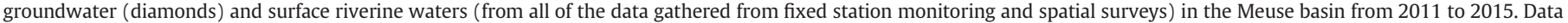
from the Geer (dark circles) are separated from the other rivers for the basin referred to as "Meuse" (light circles). Data of pCO $\mathrm{Cr}_{2}$ are unavailable for the Geer.

waters were positively correlated $\left(\mathrm{r}^{2}=0.60, \mathrm{p}<0.0001, \mathrm{n}=180\right)$ this would suggest that most of the $\mathrm{CO}_{2}$ in riverine waters might also have resulted from in-stream production. Extremely high $\mathrm{N}_{2} \mathrm{O}$ values were observed in groundwater (maximum $418,920 \%$ or $37,060 \mathrm{nmol} \mathrm{L}^{-1}$ ) that are among the highest reported in groundwater (Jurado et al., 2017). This is probably related to a strong contamination of groundwater in Belgium by $\mathrm{NO}_{3}^{-}$from use of artificial fertilizers (e.g. Orban et al., 2010; Hakoun et al., 2017). Further, oxic conditions prevail in groundwater of the shallow (1-100 $\mathrm{m}$ ) and unconfined sampled aquifers (mostly fractured limestone aquifers) that dominate in Wallonia. The $\% \mathrm{O}_{2}$ values in the sampled groundwater stations ranged between 1.8 and $97.4 \%$, and averaged $55.1 \%$ (Table 2). Due to general oxic conditions, the removal of $\mathrm{NO}_{3}^{-}$by denitrification is likely to be low in groundwater in Wallonia. These oxic conditions also explain the low $\mathrm{CH}_{4}$ concentrations in the Meuse groundwater (Table 2). The average of DIN was higher in groundwater $\left(526 \mu \mathrm{mol} \mathrm{L}{ }^{-1}\right.$, Table 2$)$ than in surface waters (266 $\mu \mathrm{mol} \mathrm{L}^{-1}$ ), as well as $\mathrm{N}_{2} \mathrm{O}, 70,027$ and $183 \%$, respectively. Hence, part of $\mathrm{N}_{2} \mathrm{O}$ in rivers could come from groundwater in the Meuse basin, although the actual fraction remains to be quantified.

The spatial variations in surface riverine waters were in part related to the stream/river size, with a decreasing pattern of $\mathrm{CO}_{2}$ and $\mathrm{CH}_{4}$ with Strahler order mirrored by an increase of $\mathrm{O}_{2}$ (Fig. 9). Such a pattern has been previously reported for $\mathrm{CO}_{2}$ in US rivers (Butman and Raymond, 2011), and might be interpreted as resulting from decreasing input of $\mathrm{CO}_{2}$ rich groundwater with increasing Strahler order (Hotchkiss et al., 2015). However, this is inconsistent with the decreasing pattern of $\mathrm{CH}_{4}$ with Strahler order since groundwater in the Meuse basin has low $\mathrm{CH}_{4}$ concentrations (Fig. 8). There was an increasing pattern of TSM and POC with Strahler order, while other variables such as DOC and DIN showed no discernible patterns with Strahler order.

Besides the size of streams and rivers, the catchment characteristics, such as lithology and land cover, control water composition and biogeochemical processes (e.g. Kempe, 1984; Meybeck, 1987). TSM, POC, DOC and DIN were positively related to the fraction of agriculture cover of 

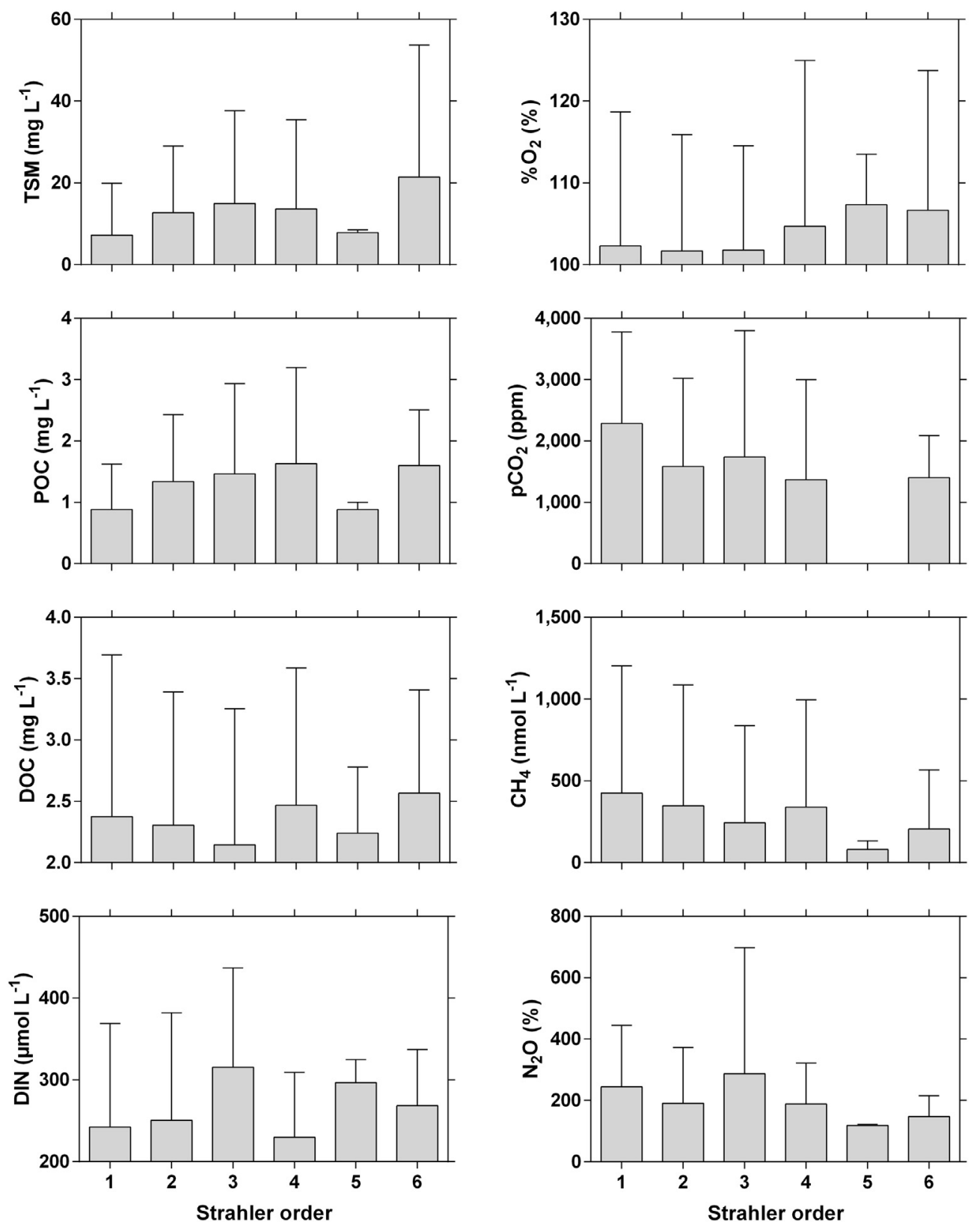

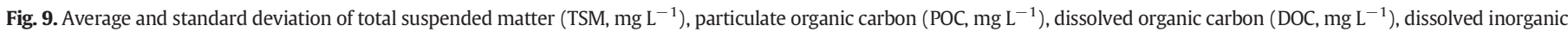

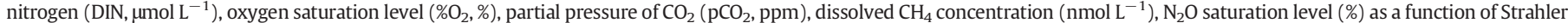
order from the four spatial surveys in the Meuse basin (summer 2013 and in late winter 2013, 2014 and 2015).

the catchment (Fig. 10), whereby agriculture cover is the sum of cropland and pasture, with an overall dominance in the data-set of cropland that represented on average $33 \%$ of the cover over studied catchments, while pastures represented 19\%. TSM, POC/DOC and DIN patterns reflect the delivery of nutrients, particulate organic matter and DOM to fluvial systems from agricultural catchments. A parallel study showed the increasing fraction of agriculture cover of the catchment also affected the quality of DOM delivered to the rivers that tended to be more labile (Lambert et al., 2017), in agreement with a similar study in German rivers (Bodmer et al., 2016). The delivery of more labile DOM is consistent with the decrease of $\mathrm{O}_{2}$ and increase of $\mathrm{pCO}_{2}$ and $\mathrm{CH}_{4}$ with the increasing fraction of agriculture cover due to enhanced in-stream microbial activity. The parallel increase of $\mathrm{N}_{2} \mathrm{O}$ could result from both the increase of DIN and decrease of $\mathrm{O}_{2}$, as the yield of $\mathrm{N}_{2} \mathrm{O}$ production from nitrification or denitrification is highest at low $\mathrm{O}_{2}$ levels (Codispoti and Christensen, 1985). An increased delivery of dissolved organic nitrogen to rivers from agricultural catchments has been also been reported (Graeber et al., 2012) although not measured during the present study. Forest was the main catchment land cover substituting agriculture when the latter was a less prominent land use type (Supplemental Fig. 1 ). The comparison of catchments mainly occupied ( $>60 \%$ ) by forest and by agriculture also showed the importance of agriculture on the catchment in generating GHGs in the river network (Fig. 11).

Catchments dominated by agriculture compared to those dominated by forest were characterized by higher TSM, POC, DOC, consequently by higher $\mathrm{pCO}_{2}$ and $\mathrm{CH}_{4}$, and lower $\% \mathrm{O}_{2}$, and by higher DIN, consequently by higher $\mathrm{N}_{2} \mathrm{O}$ (Fig. 11). This conclusion is different from the study of Butman and Raymond (2011) that showed higher $\mathrm{CO}_{2}$ values associated to forested watersheds across the US. This difference might be due to cross-correlations of land cover with altitude and precipitation that also affect $\mathrm{CO}_{2}$ in the large scale study across the US compared to our much smaller scale regional study. Our results converge with those of 

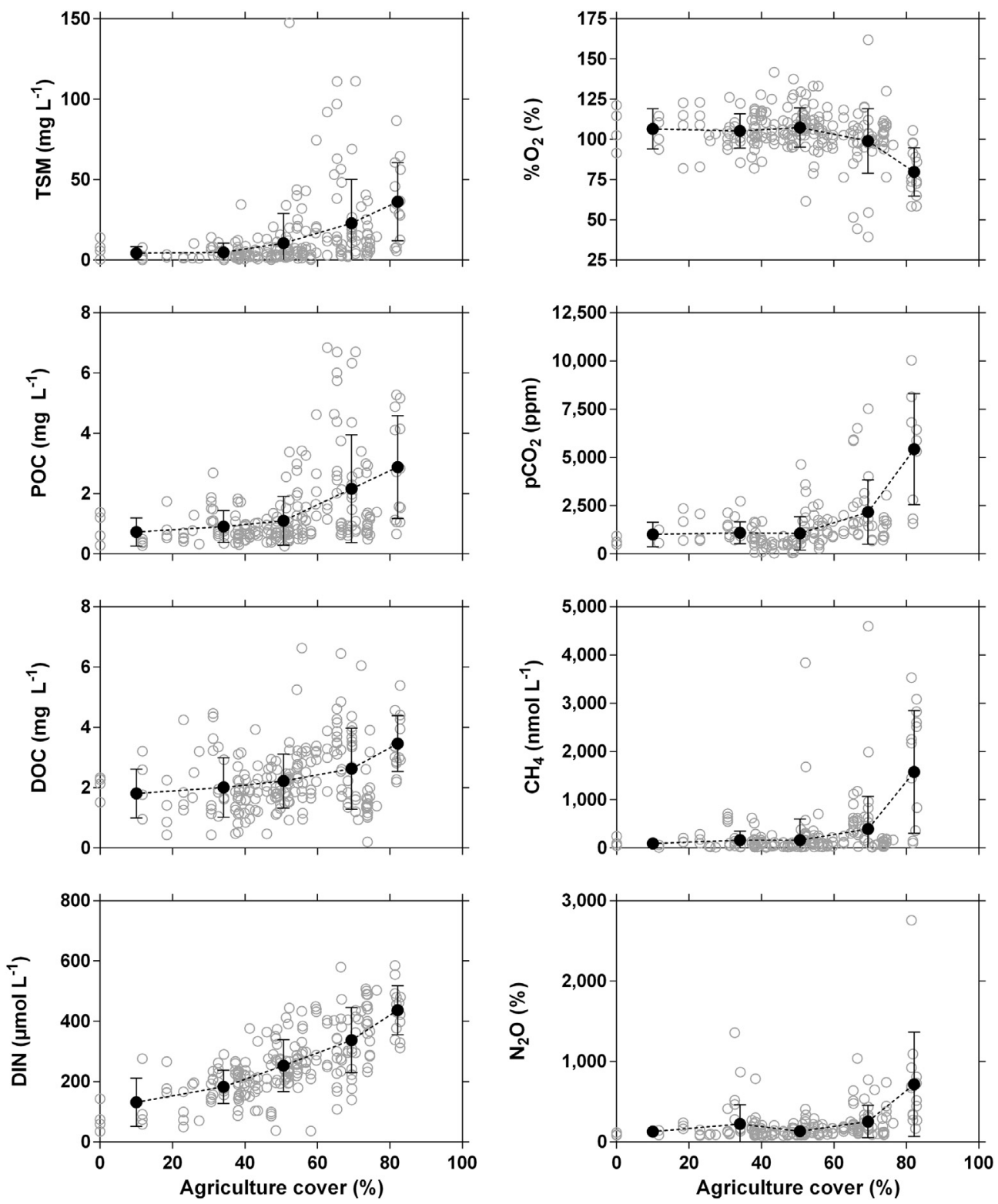

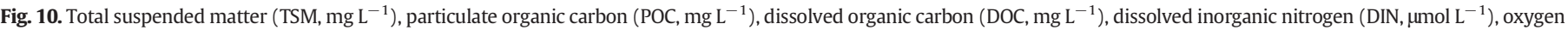

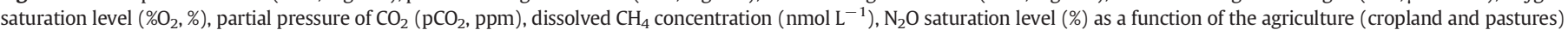

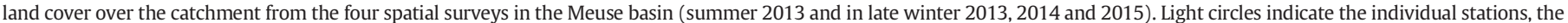
dark circles indicate the average and standard deviation of data-bins every $20 \%$ of agriculture cover.

Bodmer et al. (2016) that also showed an increase of $\mathrm{CO}_{2}$ in agriculture impacted streams in Germany compared to forested ones, but not for $\mathrm{CH}_{4}$. Urban areas occupied on average $9 \%$ of the land cover in the sampled sub-catchments but there were no significant correlations between sampled variables and urban area cover (not shown). Large cities can lead to an increase of fluvial GHGs, as shown for $\mathrm{CH}_{4}$ in the Seine River in response to effluent inputs from the city of Paris (Garnier et al., 2013). However, such effects are very local and large scale spatial variations of fluvial GHGs seem to be related to variations of the more dominant land cover such as agriculture and forest. Furthermore, about $80 \%$ of domestic wastewater from urban agglomerations in Wallonia is nowadays collected and processed in wastewater treatment plants.

Finally, in order to further characterize human-impacted river networks compared to relatively pristine ones, and also to compare temperate and tropical rivers we compared $\mathrm{CH}_{4}$ and $\mathrm{N}_{2} \mathrm{O}$ in the Meuse with our own data-sets obtained in the Congo and Zambezi rivers
(Borges et al., 2015a; Teodoru et al., 2015) (Fig. 12). At moderate and high $\mathrm{O}_{2}$ levels $\left(\% \mathrm{O}_{2}>50 \%\right)$, the $\mathrm{CH}_{4}$ in the Meuse basin was lower (average $203 \mathrm{nmol} \mathrm{L}^{-1}$ ) than in the Congo and Zambezi (average 351 and $325 \mathrm{nmol} \mathrm{L}^{-1}$, respectively), owing to higher temperatures and organic matter inputs typical of tropical rivers. However, the Geer River, highly impacted by agriculture and with a high water residence time owing its impounded nature, was characterized by much higher $\mathrm{CH}_{4}$ average concentrations $\left(6709 \mathrm{nmol} \mathrm{L}^{-1}\right.$ ) than the Congo and the Zambezi ( 3073 and $4440 \mathrm{nmol} \mathrm{L}^{-1}$, respectively) within the same $\% \mathrm{O}_{2}$ range (5-60\%). The highest $\mathrm{CH}_{4}$ concentrations were observed in the wetlands of the Congo (up to $56,240 \mathrm{nmol} \mathrm{L}^{-1}$ ) where nearly anoxic conditions were observed in surface waters (Fig. 11). At low $\mathrm{O}_{2}$ values $\left(\% \mathrm{O}_{2}<50 \%\right)$, the $\mathrm{N}_{2} \mathrm{O}$ distribution is radically different, with values close to or below saturation in the Congo and Zambezi (100 and 69\%, respectively) in these DIN poor systems (average $\sim 15 \mu \mathrm{mol} \mathrm{L}^{-1}$ for both rivers), due to low pressure of agriculture (that is not based anyway on artificial fertilizers) in these two near pristine systems. On the 

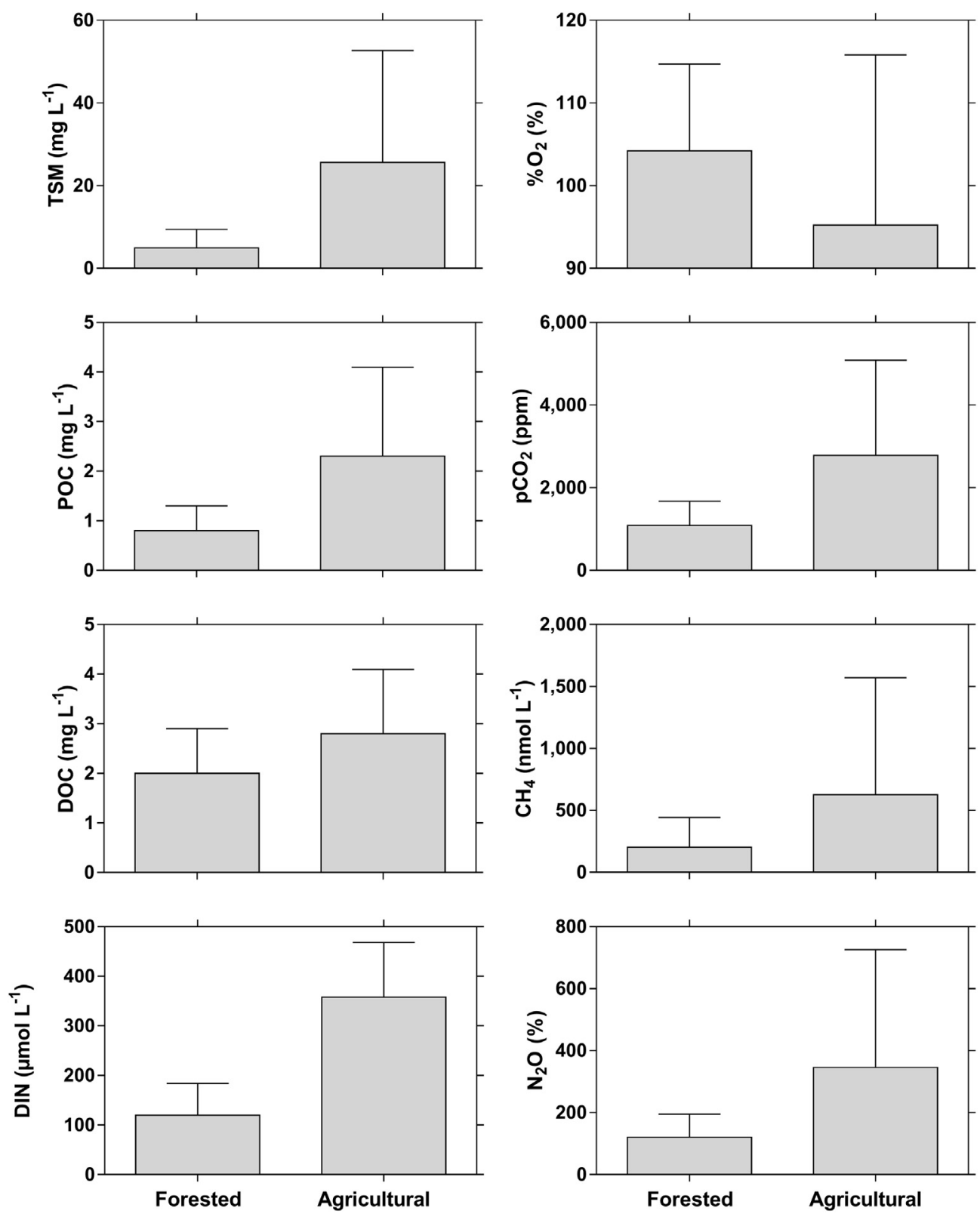

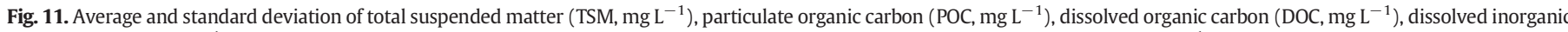

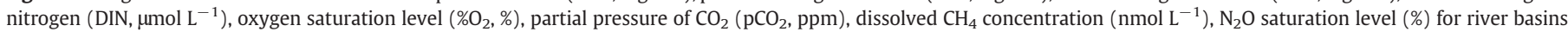
dominated by forest ( $>60 \%$ of cover) and by agriculture (cropland and pastures) ( $>60 \%$ of cover).

contrary, the $\mathrm{N}_{2} \mathrm{O}$ levels strongly increase in the Meuse basin owing to much higher DIN values (average $265 \mu \mathrm{mol} \mathrm{L}^{-1}$ ), in particular in the Geer (Fig.10, Table 2), due leaching from agricultural soils strongly impacted by the use of artificial fertilizers (Hakoun et al., 2017).

\section{Conclusions}

A recent synthesis on the sensitivity of river ecosystem processes to environmental stressors (von Schiller et al., 2017) did not list GHG emissions among the riverine processes, although these are known to be important in global budgets. The present study showed that surface waters of the rivers and streams of Meuse river network were oversaturated in $\mathrm{CO}_{2}, \mathrm{CH}_{4}, \mathrm{~N}_{2} \mathrm{O}$ with respect to atmospheric equilibrium, which should lead to an emission of these GHGs to the atmosphere, although not quantified in the present study. This study also adds to others that show that GHG emissions from inland waters are sensitive to human modifications of hydrology and catchment land use. Cropland and pasture cover about $40 \%$ of the Earth's ice-free surface area (Foley et al., 2005). Here, we show that the concentrations of dissolved $\mathrm{CO}_{2}, \mathrm{CH}_{4}$ and $\mathrm{N}_{2} \mathrm{O}$ in rivers - and hence, their emissions, increased with fraction of agriculture on the catchment owing to a larger delivery of DIN and organic matter. Agriculture (livestock and rice cultivation) contributes globally to about $57 \%$ of total anthropogenic $\mathrm{CH}_{4}$ emissions (Saunois et al., 2016). Here, we show that rivers can be an additional source of $\mathrm{CH}_{4}$ related to agricultural practise (croplands and pastures) that has not been previously accounted, although already acknowledged for $\mathrm{N}_{2} \mathrm{O}$ (Yu et al., 2013). Unlike impounded rivers such as the Mississippi where low $\mathrm{CO}_{2}$ values have been reported due to planktonic primary production (Crawford et al., 2016), the Meuse was characterized by $\mathrm{CO}_{2}$ oversaturation that increased in summer. This difference might result from the occurrence of invasive benthic filter feeders (mussels and clams) that exert a strong top-down control on phytoplankton development that is nowadays confined to early spring in the Meuse. Comparison with pristine tropical rivers showed that the use of artificial 

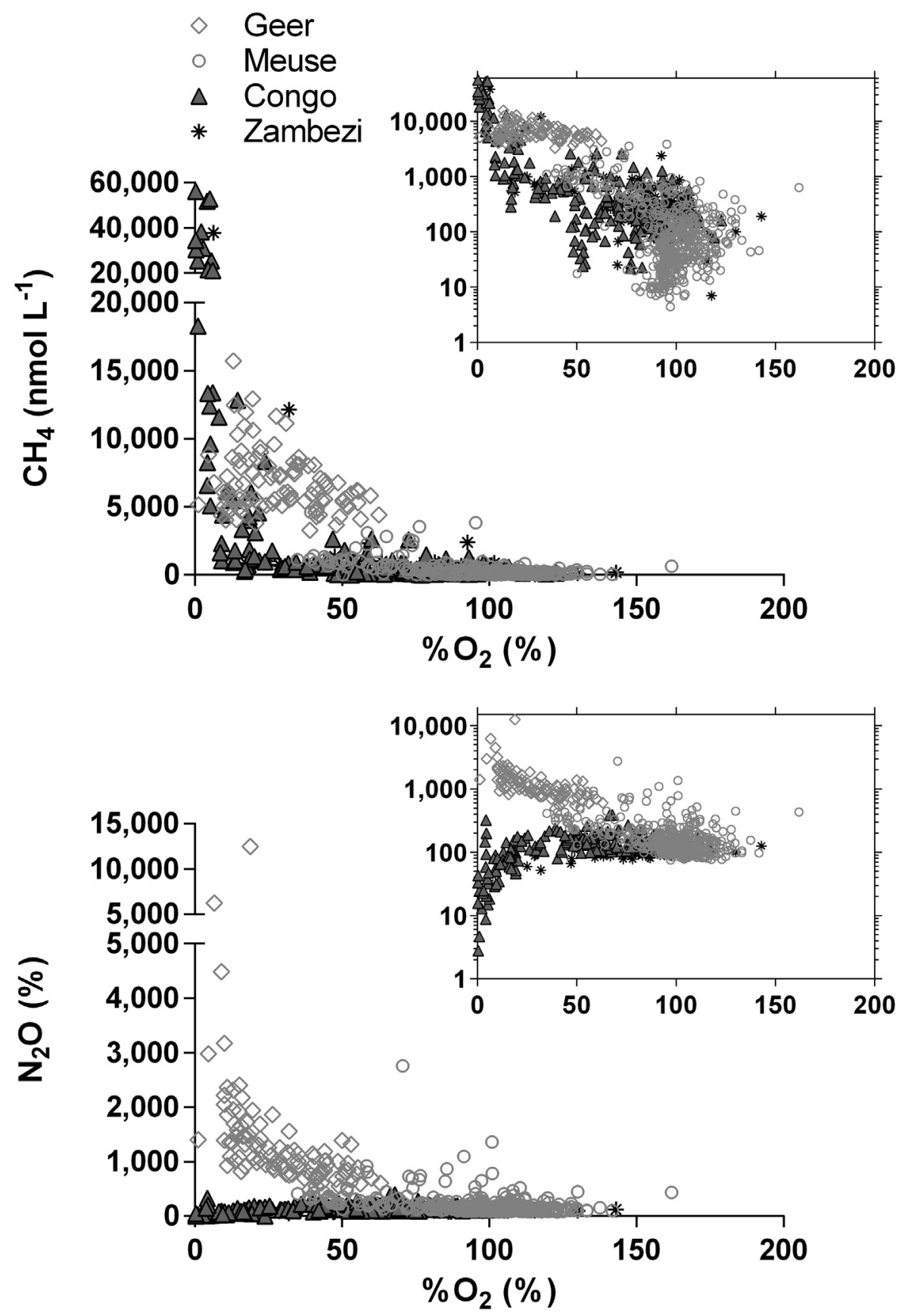

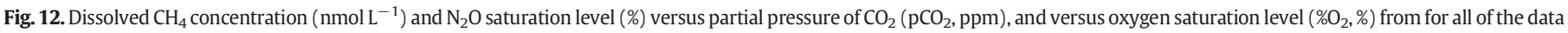

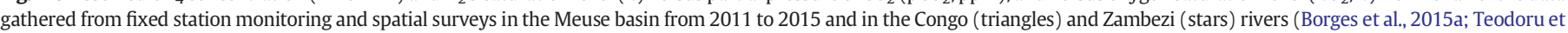

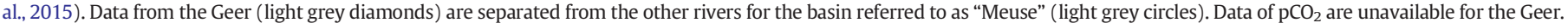

fertilizers on the catchments strongly enhanced $\mathrm{N}_{2} \mathrm{O}$ production, while DIN poor pristine systems tended to be sinks of $\mathrm{N}_{2} \mathrm{O}$ at low $\mathrm{O}_{2}$ levels, probably owing to sediment denitrification.

Supplementary data to this article can be found online at http://dx. doi.org/10.1016/j.scitotenv.2017.08.047.

\section{Acknowledgements}

This is a contribution to the WAL-H2O-GHG project funded by the Walloon Institute of Sustainable Development and the Fonds National de la Recherche Scientifique (FNRS) (project n X.3007.17). We thank Aurore Beulen, Jonathan Reichling, Stephane Hoornaert, Marc-Vincent Commarieu, Jérôme Harlay, Sandro Petrovic and Bruno Leporcq for help in sampling and analytical support, the DGO2 (Direction
Générale Opérationnelle de la Mobilité et des Voies hydrauliques) of the Service Public de Wallonie (SPW) for providing freshwater discharge data, the DGO3 (Direction Générale Opérationnelle Agriculture, Ressources naturelles et Environnement) and the Institut Scientifique de Service Public and for help during the groundwater samplings, and three anonymous reviewers for helpful comments on a previous version of the manuscript. VH acknowledges funding from the European Commission through the Marie Skłodowska-Curie International Training Network Advocate (Project No. 265063). AJ gratefully acknowledges the financial support from the University of Liège and the European Commission through the Marie Skłodowska-Curie BeIPDCOFUND postdoctoral fellowship programme (2015-2017 fellows from FP7-MSCA-COFUND, 600405). AVB is a senior research associate at the FNRS. 


\section{References}

Abril, G., Etcheber, H., Borges, A.V., Frankignoulle, M., 2000. Excess atmospheric carbon dioxide transported by rivers into the Scheldt Estuary. C.R. Acad. Sci., Ser. Ila: Sci. Terre Planets 330, 761-768.

Abril, G., Martinez, J.-M., Artigas, L.F., Moreira-Turcq, P., Benedetti, M.F., Vidal, L., Meziane, T., Kim, J.-H., Bernardes, M.C., Savoye, N., Deborde, J., Albéric, P., Souza, M.F.L., Souza E.L., Roland, F., 2014. Amazon River carbon dioxide outgassing fuelled by wetlands. Nature 505, 395-398.

Abril, G., Bouillon, S., Darchambeau, F., Teodoru, C.R., Marwick, T.R., Tamooh, F., Omengo, F.O., Geeraert, N., Deirmendjian, L., Polsenaere, P., Borges, A.V., 2015. Technical note: large overestimation of $\mathrm{pCO}_{2}$ calculated from $\mathrm{pH}$ and alkalinity in acidic, organic-rich freshwaters. Biogeosciences 12, 67-78.

Alshboul, Z., Encinas-Fernandéz, J., Hofmann, H., Lorke, A., 2016. Export of dissolved methane and carbon dioxide with effluents from municipal wastewater treatment plants. Environ. Sci. Technol. 50, 5555-5563.

APHA, 1998. Standard Methods for the Examination of Water and Wastewater. American Public Health Association.

Bastviken, D., Tranvik, L.J., Downing, J.A., Crill, P.M., Enrich-Prast, A., 2011. Freshwater methane emissions offset the continental carbon sink. Science 331, 50 .

Baulch, H.M., Schiff, S.L., Maranger, R., Dillon, P.J., 2011. Nitrogen enrichment and the emission of nitrous oxide from streams. Glob. Biogeochem. Cycles 25, GB4013. http://dx.doi.org/10.1029/2011GB004047.

Beaulieu, J.J., Tank, J.L., Hamilton, S.K., Wollheim, W.M., Hall Jr., R.O., Mulholland, P.J., Peterson, B.J., Ashkenas, L.R., Cooper, L.W., Dahm, C.N., Dodds, W.K., Grimm, N.B. Johnson, S.L., McDowell, W.H., Poole, G.C., Valett, H.M., Arango, C.P., Bernot, M.J., Burgin, A.J., Crenshaw, C.L., Helton, A.M., Johnson, L.T., O'Brien, J.M., Potter, J.D., Sheibley, R.W., Sobota, D.J., Thomas, S.M., 2011. Nitrous oxide emission from denitrification in stream and river networks. Proc. Natl. Acad. Sci. U. S. A. 108, 214-219.

Bloom, A.A., Palmer, P.I., Fraser, A., Reay, D.S., Frankenberg, C., 2010. Large-scale controls of methanogenesis inferred from methane and gravity spaceborne data. Science 327, 322-325.

Bodmer, P., Heinz, M., Pusch, M., Singer, G., Premke, K., 2016. Carbon dynamics and their link to dissolved organic matter quality across contrasting stream ecosystems. Sci. Total Environ. 553, 574-586.

Borges, A.V., Darchambeau, F., Teodoru, C.R., Marwick, T.R., Tamooh, F., Geeraert, N., Omengo, F.O., Guérin, F., Lambert, T., Morana, C., Okuku, E., Bouillon, S., 2015a. Globally significant greenhouse gas emissions from African inland waters. Nat. Geosci. 8, 637-642.

Borges, A.V., Abril, G., Darchambeau, F., Teodoru, C.R., Deborde, J., Vidal, L.O., Lambert, T., Bouillon, S., 2015b. Divergent biophysical controls of aquatic $\mathrm{CO}_{2}$ and $\mathrm{CH} 4$ in the World's two largest rivers. Sci Rep 5:15614. http://dx.doi.org/10.1038/srep15614.

Butman, D., Raymond, P.A., 2011. Significant efflux of carbon dioxide from streams and rivers in the United States. Nat. Geosci. 4, 839-842.

Caraco, N.F., Cole, J.J., Raymond, P.A., Strayer, D.L., Pace, M.L., Findlay, S.E.G., Fischer, D.T., 1997. Zebra mussel invasion in a large, turbid river: phytoplankton response to increased grazing. Ecology 78, 588-602.

Codispoti, L.A., Christensen, J.P., 1985. Nitirification, denitrification and nitroux oxide cycling in the Eastern tropical South Pacific Ocean. Mar. Chem. 16, 277-300.

Cole, J.J., Caraco, N.F., 2001. Carbon in catchments: connecting terrestrial carbon losses with aquatic metabolism. Mar. Freshw. Res. 52, 101-110.

Crawford, J.T., Loken, L.C., Stanley, E.H., Stets, E.G., Dornblaser, M.M., Striegl, R.G., 2016. Basin scale controls on $\mathrm{CO}_{2}$ and $\mathrm{CH}_{4}$ emissions from the upper Mississippi River. Geophys. Res. Lett. 43, 1973-1979.

Descy, J.-P., Servais, P., Smitz, J.S., Billen, G., Everbecq, E., 1987. Phytoplankton biomass and production in the river meuse (Belgium). Water Res. 21, 1557-1566.

Descy, J.-P., Leporcq, B., Viroux, L., François, C., Servais, P., 2002. Phytoplankton production, exudation and bacterial reassimilation in the River Meuse (Belgium). J. Plankton Res. 24, 161-166.

Descy, J.-P., Everbecq, E., Gosselain, V., Viroux, L., Smitz, J.S., 2003. Modelling the impact of benthic filter-feeders on the composition and biomass of river plankton. Freshw. Biol. 48, 404-417.

Descy, J.-P., Hardy, M.-A., Sténuite, S., Pirlot, S., Leporcq, B., Kimirei, I., Sekadende, B., Mwaitega, S.R., Sinyenza, D., 2005. Phytoplankton pigments and community composition in Lake Tanganyika. Freshw. Biol. 50, 668-684.

Descy, J.-P., Patrick, K., Everbecq, E., Verniers, G., Usseglio-Polatera, P., Gérard, P., Viroux, L., Beisel, J.-N., Smitz, J., 2009. Continental Atlantic Rivers. In: Tockner, Klement, Uehlinger, Urs, Robinson, Christopher T. (Eds.), Rivers of Europe. Academic Press, London, pp. 151-198.

Dong, L.F., Nedwell, D.B., Colbeck, I., Finch, J., 2005. Nitrous oxide emission from some English and Welsh rivers and estuaries. Water Air Soil Pollut. Focus 4, 127-134.

EEA, 2014. European Environmental Agency, Corine Land Cover 2006 raster data. Retrieved from. http://www.eea.europa.eu/data-and-maps/data/corine-land-cover2006-raster-3.

Evans, M.A., Fahnenstiel, G., Scavia, D., 2011. Incidental oligotrophication of North American Great Lakes. Environ. Sci. Technol. 45, 3297-3303.

Everbecq, E., Gosselain, V., Viroux, L., Descy, J.-P., 2001. Potamon: a dynamic model for predicting phytoplankton composition and biomass in lowland rivers. Water Res. 35, 901-912.

Foley, J., DeFries, R., Asner, C., Barford, G., Bonan, S.R., Carpenter, F.S., Chapin, M.T., Coe, G.C., Daly, H.K., Gibbs, J.H., Helkowski, T., Hollaway, E.A., Howard, C.J., Kucharik, C., Monfreda, C., Patz, A., Prentice, I.C., Ramankutty, N., Snyder, P.K., 2005. Global consequences of land use. Science 309, 570-574.

Garnier, J., Billen, G., Vilain, G., Martinez, A., Silvestre, M., Mounier, E., Toche, F., 2009. Nitrous oxide $\left(\mathrm{N}_{2} \mathrm{O}\right)$ in the Seine river and basin: observations and budgets. Agric. Agric. Ecosyst. Environ. 133, 223-233.
Garnier, J., Vilain, G., Silvestre, M., Billen, G., Jehanno, S., Poirier, D., Martinez, A., Decuq, C. Cellier, P., Abril, G., 2013. Budget of methane emissions from soils, livestock and the river network at the regional scale of the Seine basin (France). Biogeochemistry $116,199-214$.

Graeber, D., Gelbrecht, J., Pusch, M.T., Anlanger, C., von Schiller, D., 2012. Agriculture has changed the amount and composition of dissolved organic matter in Central European headwater streams. Sci. Total Environ. 438, 435-446.

Graeber, D., Boëchat, I.G., Encina-Montoya, F., Esse, C., Gelbrecht, J., Goyenola, G., Gücker, B., Heinz, M., Kronvang, B., Meerhoff, M., Nimptsch, J., Pusch, M.T., Silva, R.C., von Schiller, D., Zwirnmann, E., 2015. Global effects of agriculture on fluvial dissolved organic matter. Sci Rep 5:16328. http://dx.doi.org/10.1038/srep16328.

Hakoun, V., Orban, P., Dassargues, A., Brouyère, S., 2017. Factors controlling spatial and temporal patterns of multiple pesticide compounds in groundwater (Hesbaye chalk aquifer, Belgium). Environ. Pollut. 223, 185-199.

Hotchkiss, E.R., Hall Jr., R.O., Sponseller, R.A., Butman, D., Klaminder, J., Laudon, H., Rosvall, M., Karlsson, J., 2015. Sources of and processes controlling $\mathrm{CO}_{2}$ emissions change with the size of streams and rivers. Nat. Geosci. 8, 696-699.

Hu, M., Chen, D., Dahlgren, R.A., 2016. Modeling nitrous oxide emission from rivers: global assessment. Glob. Chang. Biol. 22, 3566-3582.

Hussner, A., 2009. Growth and photosynthesis of four invasive aquatic plant species in Europe. Weed Res. 49, 506-515.

Hussner, A., 2012. Alien aquatic plant species in European countries. Weed Res. 52, 297-306.

Johnson, M.S., Lehmann, J., Riha, S.J., Krusche, A.V., Richey, J.E., Ometto, J.P.H.B., Couto, E.G., 2008. $\mathrm{CO}_{2}$ efflux from Amazonian headwater streams represents a significant fate for deep soil respiration. Geophys. Res. Lett. 35, L17401. http://dx.doi.org/10.1029/ 2008GL034619.

Jurado, A., Borges, A.V., Brouyère, S., 2017. Dynamics and emissions of $\mathrm{N}_{2} \mathrm{O}$ in groundwater: a review. Sci. Total Environ. 584-585, 207-218.

Kempe, S., 1984. Sinks of the anthropogenically enhanced carbon cycle in surface fresh waters. J. Geophys. Res. 89, 4657-4676.

Koné, Y.J.M., Abril, G., Kouadio, K.N., Delille, B., Borges, A.V., 2009. Seasonal variability of carbon dioxide in the rivers and lagoons of Ivory Coast (West Africa). Estuar. Coasts $32,246-260$.

Koné, Y.J.M., Abril, G., Delille, B., Borges, A.V., 2010. Seasonal variability of methane in the rivers and lagoons of Ivory Coast (West Africa). Biogeochemistry 100, 21-37.

Lambert, T., Bouillon, S., Darchambeau, F., Morana, C., Roland, F., Descy, J.-P., Borges, A.V. 2017. Effects of human land use on the terrestrial and aquatic sources of fluvial organic matter in a temperate river basin (The Meuse River, Belgium) (submitted).

Lauerwald, R., Laruelle, G.G., Hartmann, J., Ciais, P., Regnier, P.A.G., 2015. Spatial pattern in $\mathrm{CO}_{2}$ evasion from the global river network. Glob. Biogeochem. Cycles 29, 534-554.

Maeck, A., Delsontro, T., McGinnis, D.F., Fischer, H., Flury, S., Schmidt, M., Fietzek, P., Lorke A., 2013. Sediment trapping by dams creates methane emission hot spots. Environ. Sci. Technol. 47, 8130-8137.

Marescaux, J., Boets, P., Lorquet, J., Sablon, R., Van Doninck, K., Beisel, J.-N., 2015. Sympatric Dreissena species in the Meuse River: towards a dominance shift from zebra to quagga mussels. Aquat. Invasions 10, 287-298.

Marwick, T.R., Tamooh, F., Ogwoka, B., Teodoru, C., Borges, A.V., Darchambeau, F., Bouillon, S., 2014. Dynamic seasonal nitrogen cycling in response to anthropogenic N loading in a tropical catchment, Athi-Galana-Sabaki River, Kenya. Biogeosciences 11, 1-18.

Meybeck, M., 1987. Global chemical weathering of surficial rocks estimated from river dissolved loads. Am. J. Sci. 287, 401-428.

Orban, P., Brouyère, S., Batlle-Aguilar, J., Couturier, J., Goderniaux, P., Leroy, M. Maloszewski, P., Dassargues, A., 2010. Regional transport modelling for nitrate trend assessment and forecasting in a chalk aquifer. J. Contam. Hydrol. 118, 79-93.

Pigneur, L.M., Falisse, E., Roland, K., Everbecq, E., Deliège, J.F., Smitz, J.S., Doninck, K., Descy, J.P., 2014. Impact of invasive Asian clams, Corbicula spp., on a large river ecosystem. Freshw. Biol. 59, 573-583.

Rajkumar, A.N., Barnes, J., Ramesh, R., Purvaja, R., Upstill-Goddard, R.C., 2008. Methane and nitrous oxide fluxes in the polluted Adyar River and estuary, SE India. Mar. Pollut. Bull. 56, 2043-2051.

Raymond, P.A., Zappa, C.J., Butman, D., Bott, T.L., Potter, C., Mulholland, P., Laursen, A.E., McDowell, W.H., Newbold, D., 2012. Scaling the gas transfer velocity and hydraulic geometry in streams and small rivers. Limnol. Oceanogr. Fluids Environ. 2, 41-53.

Raymond, P.A., Hartmann, J., Lauerwald, R., Sobek, S., McDonald, C., Hoover, M., Butman, D. Striegl, R., Mayorga, E., Humborg, C., Kortelainen, P., Dürr, H., Meybeck, M., Ciais, P., Guth, P., 2013. Global carbon dioxide emissions from inland waters. Nature 503, 355-359.

Richey, J.E., Devol, A.H., Wofy, S.C., Victoria, R., Riberio, M.N.G., 1988. Biogenic gases and the oxidation and reduction of carbon in Amazon River and floodplain waters. Limnol. Oceanogr. 33, 551-561.

Richey, J.E., Melack, J.M., Aufdenkampe, A.K., Ballester, V.M., Hess, L., 2002. Outgassing from Amazonian rivers and wetlands as a large tropical source of atmospheric $\mathrm{CO}_{2}$. Nature 416, 617-620.

Saunois, M., Bousquet, P., Poulter, B., Peregon, A., Ciais, P., Canadell, J.G., Dlugokencky, E.J Etiope, G., Bastviken, D., Houweling, S., Janssens-Maenhout, G., Tubiello, F.N., Castaldi, S., Jackson, R.B., Alexe, M., Arora, V.K., Beerling, D.J., Bergamaschi, P., Blake, D.R. Brailsford, G., Brovkin, V., Bruhwiler, L., Crevoisier, C., Crill, P., Kovey, K., Curry, C. Frankenberg, C., Gedney, N., Höglund-Isaksson, L., Ishizawa, M., Ito, A., Joos, F., Kim, H.-S., Kleinen, T., Krummel, P., Lamarque, J.-F., Langenfelds, R., Locatelli, R., Machida, T., Maksyutov, S., McDonald, K.C., Marshall, J., Melton, J.R., Morino, I., Naik, V., O'Doherty, S., Parmentier, F.-J.W., Patra, P.K., Peng, C., Peng, S., Peters, G., Pison, I, Prigent, C., Prinn, R., Ramonet, M., Riley, W.J., Saito, M., Sanyini, M., Schroeder, R. Simpson, I.J., Spahni, R., Steele, P., Takizawa, A., Thornton, B.F., Tian, H., Tohjima, Y. Viovy, N., Voulgarakis, A., van Weele, M., van der Werf, G., Weiss, R., Wiedinmyer C. Wilton, D.J., Wiltshire, A., Worthy, D., Wunch, D.B., Xu, X., Yoshida, Y., Zhang. B. Zhang, Z., Zhu, Q., 2016. The global methane budget. Earth Syst. Sci. Data 8, 697-751. 
Schade, J.D., Bailio, J., McDowell, W.H., 2016. Greenhouse gas flux from headwater streams in New Hampshire, USA: patterns and drivers. Limnol. Oceanogr. 61, S165-S174.

von Schiller, D., Acuña, V., Aristi, I., Arroita, M., Basaguren, A., Bellin, A., Boyero, L. Butturini, A., Ginebreda, A., Kalogianni, E., Larrañaga, A., Majone, B., Martínez, A., Monroy, S., Muñoz, I., Paunović, M., Pereda, O., Petrovic, M., Pozo, J., RodríguezMozaz, S., Rivas, D., Sabater, S., Sabater, F., Skoulikidis, N., Solagaistua, L., Vardakas, L., Elosegi, A., 2017. River ecosystem processes: a synthesis of approaches, criteria of use and sensitivity to environmental stressors. Sci. Total Environ. 596-597. 465-480.

Seitzinger, S.P., Kroeze, C., 1998. Global distribution of nitrous oxide production and $\mathrm{N}$ inputs in freshwater and coastal marine ecosystems. Glob. Biogeochem. Cycles 12, 93-113.

Servais, P., 1989. Bacterioplankton biomass and production in the river Meuse (Belgium). Hydrobiologia 174, 99-110.

Sieczko, A.K., Demeter, K., Singer, G.A., Tritthart, M., Preiner, S., Mayr, M., Meisterl, K. Peduzzi, P., 2016. Aquatic methane dynamics in a human-impacted river-floodplain of the Danube. Limnol. Oceanogr. 61, S175-S187.
Standing committee of Analysts, 1981. Ammonia in waters. Methods for the Examination of Waters and Associated Materials (16 pp.).

Stanley, E.H., Casson, N.J., Christel, S.T., Crawford, J.T., Loken, L.C., Oliver, S.K., 2016. The ecology of methane in streams and rivers: patterns, controls, and global significance. Ecol. Monogr. 86, 146-171.

Teodoru, C.R., Nyoni, F.C., Borges, A.V., Darchambeau, F., Nyambe, I., Bouillon, S., 2015. Dynamics of greenhouse gases $\left(\mathrm{CO}_{2}, \mathrm{CH}_{4}, \mathrm{~N}_{2} \mathrm{O}\right)$ along the Zambezi River and major tributaries, and their importance in the riverine carbon budget. Biogeosciences 12, 2431-2453.

Weiss, R.F., 1981. Determinations of carbon dioxide and methane by dual catalyst flame ionization chromatography and nitrous oxide by electron capture chromatography. J. Chromatogr. Sci. 19, 611-616.

Wilson, H.F., Xenopoulos, M.A., 2009. Effects of agricultural land use on the composition of fluvial dissolved organic matter. Nat. Geosci. 2, 37-41.

Yu, Z Deng, H, Wang D, Ye, M., Tan, Y. Li, Y, Chen, Z, Xu, S, 2013. Nitrous oxide emissions in the Shanghai river network: implications for the effects of urban sewage and IPCC methodology. Glob. Chang. Biol. 19, 2999-3010. 